\title{
28. TRACE ELEMENT GEOCHEMISTRY OF PERIDOTITES FROM THE IZU-BONIN-MARIANA FOREARC, LEG $125^{1}$
}

\author{
I. J. Parkinson, ${ }^{2}$ J. A. Pearce, ${ }^{2}$ M. F. Thirlwall, ${ }^{3}$ K.T.M. Johnson, ${ }^{4}$ and G. Ingram ${ }^{3}$
}

\begin{abstract}
Trace element analyses (first-series transition elements, $\mathrm{Ti}, \mathrm{Rb}, \mathrm{Sr}, \mathrm{Zr}, \mathrm{Y}, \mathrm{Nb}$, and $\mathrm{REE}$ ) were carried out on whole rocks and minerals from 10 peridotite samples from both Conical Seamount in the Mariana forearc and Torishima Forearc Seamount in the Izu-Bonin forearc using a combination of XRF, ID-MS, ICP-MS, and ion microprobe. The concentrations of incompatible trace elements are generally low, reflecting the highly residual nature of the peridotites and their low clinopyroxene content $(<2 \%)$. Chondrite-normalized REE patterns show extreme $U$ shapes with $(\mathrm{La} / \mathrm{Sm})_{n}$ ratios in the range of 5.03-250.0 and $(\mathrm{Sm} / \mathrm{Yb})_{n}$ ratios in the range of $0.05-0.25$; several samples show possible small positive Eu anomalies. LREE enrichment is common to both seamounts, although the peridotites from Conical Seamount have higher $(\mathrm{La} / \mathrm{Ce})_{n}$ ratios on extended chondrite-normalized plots, in which both REEs and other trace elements are organized according to their incompatibility with respect to a harzburgitic mantle. Comparison with abyssal peridotite patterns suggests that the LREEs, Rb, Nb, Sr, Sm, and Eu are all enriched in the Leg 125 peridotites, but $\mathrm{Ti}$ and the HREEs exhibit no obvious enrichment. The peridotites also give positive anomalies for $\mathrm{Zr}$ and $\mathrm{Sr}$ relative to their neighboring REEs. Covariation diagrams based on clinopyroxene data show that Ti and the HREEs plot on an extension of an abyssal peridotite trend to more residual compositions. However, the LREEs, $\mathrm{Rb}, \mathrm{Sr}, \mathrm{Sm}$, and Eu are displaced off this trend toward higher values, suggesting that these elements were introduced during an enrichment event. The axis of dispersion on these plots further suggests that enrichment took place during or after melting and thus was not a characteristic of the lithosphere before subduction.

Compared with boninites sampled from the Izu-Bonin-Mariana forearc, the peridotites are significantly more enriched in LREEs. Modeling of the melting process indicates that if they represent the most depleted residues of the melting events that generated forearc boninites they must have experienced subsolidus enrichment in these elements, as well as in $\mathrm{Rb}, \mathrm{Sr}, \mathrm{Zr}, \mathrm{Nb}$, $\mathrm{Sm}$, and $\mathrm{Eu}$. The lack of any correlation with the degree of serpentinization suggests that low-temperature fluids were not the prime cause of enrichment. The enrichment in the high-field-strength elements also suggests that at least some of this enrichment may have involved melts rather than aqueous fluids. Moreover, the presence of the hydrous minerals magnesio-hornblende and tremolite and the common resorption of orthopyroxene indicate that this high-temperature peridotite-fluid interaction may have taken place in a water-rich environment in the forearc following the melting event that produced the boninites. The peridotites from Leg 125 may therefore contain a record of an important flux of elements into the mantle wedge during the initial formation of forearc lithosphere. Ophiolitic peridotites with these characteristics have not yet been reported, perhaps because the precise equivalents to the serpentinite seamounts have not been analyzed.
\end{abstract}

\section{INTRODUCTION}

Bathymetric, seismic, dredging, and submersible studies of the Izu-Bonin (Ogasawara)-Mariana forearc between the outer-arc high and trench axis have led to the identification of a series of serpentinite seamounts where the "mantle wedge" is exposed at the seafloor (Bloomer, 1983; Bloomer and Hawkins, 1983; Taylor and Smoot, 1984; Ishii, 1985; Fryer and Fryer, 1987; Ishii and Robinson, this volume). During Ocean Drilling Program (ODP) Leg 125, the shipboard scientific party drilled a total of five sites on two of these seamounts (Fig. 1): two flank sites (Sites 778 and 779) and one summit site (Site 780) on Conical Seamount in the Mariana forearc and one upper flank site (Site 783) and one lower flank site (Site 784) on Torishima Forearc Seamount in the Izu-Bonin forearc. The peridotites recovered comprise about $95 \%$ harzburgites and about $5 \%$ dunites, with variable degrees (mostly $60 \%-100 \%$ ) of serpentinization. The harzburgites are highly refractory in terms of their mineralogy and geochemistry. They have low modal clinopyroxene content $(<2 \%)$, highly magnesian olivine $(\mathrm{Mg} \#=91.1-92.4)$ and orthopyroxene $(\mathrm{Mg} \#=91.5-92.5)$, chrome-rich spinel $(\mathrm{Cr} \#=60-80)$, and low $\mathrm{Ti}, \mathrm{Al}$, and $\mathrm{Ca}$ contents $\left(\mathrm{TiO}_{2}<0.01 \%\right.$ and $\mathrm{Al}_{2} \mathrm{O}_{3}$ and $\mathrm{CaO}$

\footnotetext{
${ }^{1}$ Fryer, P., Pearce, J. A., Stokking, L., B., et al., 1992. Proc, ODP, Sci. Results, 125: College Station, TX (Ocean Drilling Program).

${ }^{2}$ Department of Geological Sciences, Science Laboratories, South Road, Durham, DH1 3LE, United Kingdom.

${ }^{3}$ Department of Geology, Royal Holloway and Bedford New College, Egham Hill, Egham, Surrey, TW20 0EX, United Kingdom.

${ }^{4}$ Geological Institute, University of Tokyo, 7-3-1 Hongo, Tokyo 113, Japan.
}

$<1 \%$ ) (Ishii and Robinson, this volume). They are more refractory than the most depleted abyssal peridotites sampled to date, which suggests that the harzburgites can be interpreted as residues of extensive melting $(>20 \%)$, in one or more stages, of a fertile mantle source (Ishii and Robinson, this volume). It is generally thought that the peridotites represent residues from melting events similar to those that generated the boninites that have been sampled from the Bonin Islands, Guam, and the inner walls of the Izu-Bonin-Mariana trenches and recovered by drilling during Deep Sea Drilling Project (DSDP) Leg 60 and Leg 125 (Dobson and Tilton, 1989; Hickey-Vargas, 1989; Stern et al., 1991; Fryer, Pearce, Stokking, et al., 1990).

In terms of the rare earth elements (REEs) and other trace elements, a simple petrogenetic relationship between the peridotites and spatially related boninites is less obvious. The boninites and related rocks from the Mariana and Izu-Bonin forearcs have chondritenormalized REE patterns that range from depleted in light rare earth elements (LREEs) to various U-shaped patterns (e.g., Hickey and Frey, 1982; Murton et al., this volume). They also show variable enrichments and depletions in high-field-strength elements (HFSEs) relative to the REEs (e.g., Hickey-Vargas, 1989; Murton et al., this volume), indicating that the mantle source was highly variable along the length of the Izu-Bonin-Mariana forearc system.

Only a few extant forearc peridotites have been analyzed for incompatible trace elements at the time of writing (Masutami et al., 1988). A larger number of peridotites from supra-subduction zone ophiolites, many of which are thought to have a forearc origin (Pearce et al., 1984), have been analyzed (Kay and Sonechal, 1976; Montigny et al., 1973; Lippard et al., 1986; Suen et al., 1979; Pallister and Knight, 1981). These peridotites have REE patterns that vary 

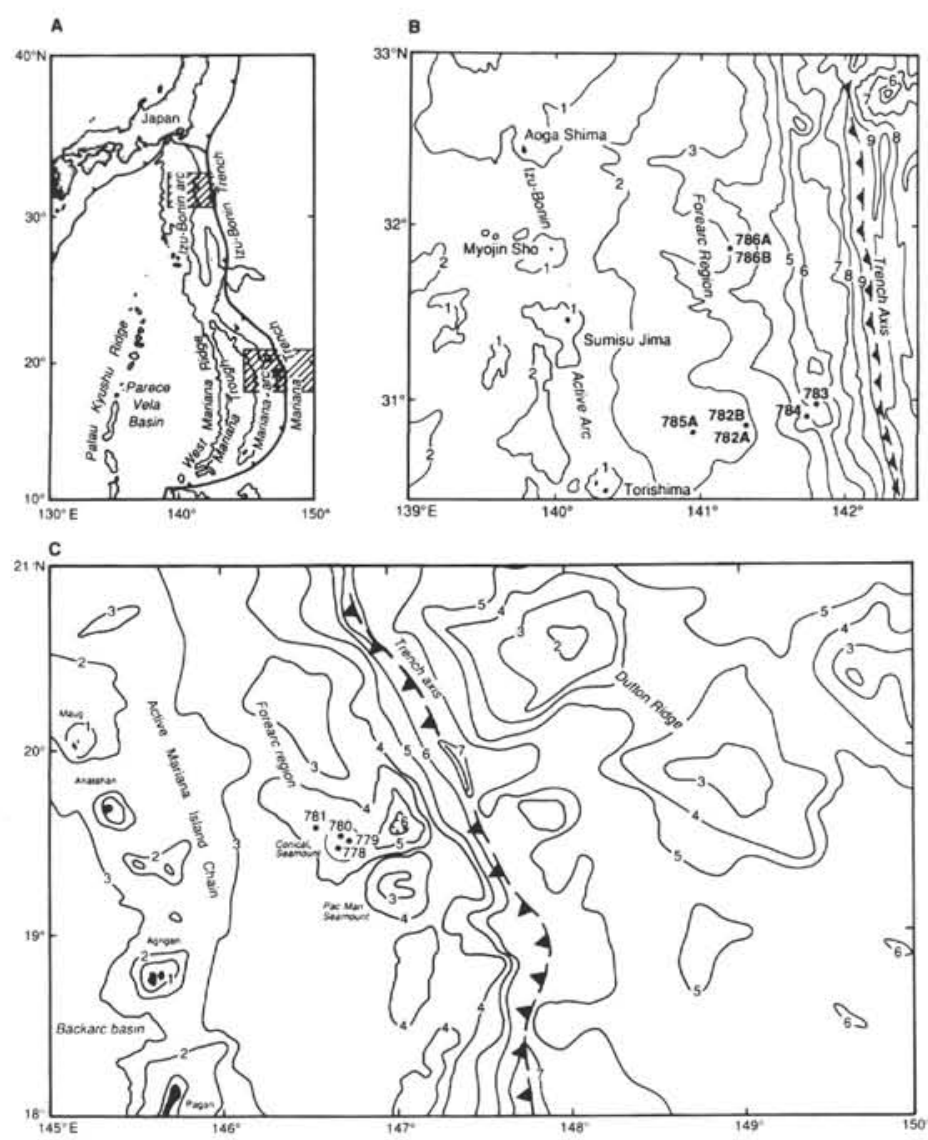

Figure 1. Location of the Leg 125 drill sites. A. Regional setting of the Izu-Bonin and Mariana forearcs. B. Izu-Bonin Sites 782 through 786. C. Mariana Sites 788 through 781. Contours in kilometers below sea level.

from LREE depleted, through flat, to LREE enriched and U shaped. It is still unclear to what extent these variations relate to differences in tectonic setting, melting processes, source composition, serpentinization, or a combination of these processes. Here we present a preliminary study of the REEs and other trace elements in a suite of peridotites and their constituent minerals from Leg 125 with three principal objectives: (1) to evaluate how fluid and melt fluxing has affected the trace element content of the peridotites, (2) to establish the petrogenetic relationships between the peridotites from Leg 125 and the boninites with which they are spatially associated, and (3) to reexamine the REE patterns of harzburgites from supra-subduction zone ophiolites in light of these new REE data from an extant forearc setting.

\section{PETROLOGY}

Ten peridotites were chosen for trace element analysis: five harzburgites from Conical Seamount (Samples 125-778A-12R-1, 43-45 cm, 125-779A-14R-1, 40-48 cm, 125-779A-26R-3, 18-25 cm, 125-780C6R-1, 61-62 cm, and 125-780C-18R-1,58-61 cm) and four harzburgites (Samples 125-784A-36R-1, 107-109 cm, 125-784A-42R-1, 7-12 cm, $125-784 \mathrm{~A}-45 \mathrm{R}-1,101-106 \mathrm{~cm}$, and $125-784 \mathrm{~A}-45 \mathrm{R}-1,130-137 \mathrm{~cm})$ and one dunite (Sample 125-784A-42R-1, 39-41 cm) from Torishima Forearc Seamount. The petrographic characteristics of the analyzed samples are given in Table 1. Full details of the compositions and textures of the tectonized harzburgites are reported by Ishii and Robinson (this volume) and Girardeau and Lagabrielle (this volume), respectively. Note that the mineral proportions listed in Table 1 are estimates of the mineral compositions before serpentinization and related alteration processes. The proportions of modal clinopyroxene are based only on discrete clinopyroxene grains and do not include clinopyroxene exsolved from orthopyroxene. Thus, the modal proportions reflect the mineralogy before subsolidus equilibration and alteration. Note also that two types of alteration assemblage are represented: the predominant lowtemperature assemblage of lizardite and chrysotile, and a higher temperature assemblage of antigorite (after olivine) and tremolite (after orthopyroxene). Chrome spinel is also variably altered to ferrit-chromite.

\section{ANALYTICAL TECHNIQUES}

\section{Bulk-Rock Analyses}

Major and some trace element $(\mathrm{V}, \mathrm{Cr}, \mathrm{Ni}, \mathrm{Cu}$, and $\mathrm{Zn})$ analyses were taken from X-ray-fluorescence (XRF) analyses carried out on glass fusion beads and powder pellets, respectively, aboard JOIDES Resolution (Fryer, Pearce, Stokking, et al., 1990). Shipboard powder pellets were rerun by XRF at University of Durham for major elements and some trace elements ( $\mathrm{Sr}, \mathrm{Sc}, \mathrm{Ti}, \mathrm{V}, \mathrm{Cr}, \mathrm{Co}, \mathrm{Ni}, \mathrm{Cu}$, and $\mathrm{Zn}$ ) using a Philips PW 1500 spectrometer and an Rh anode tube.

All the incompatible elements, except Ti, were below the XRF detection limits, and $\mathrm{Ti}$ was close to the detection limit even with using powder pellets. $\mathrm{Ti}, \mathrm{Rb}, \mathrm{Sr}, \mathrm{Y}, \mathrm{Zr}, \mathrm{Nb}, \mathrm{La}, \mathrm{Ce}$, and $\mathrm{Yb}$ were therefore analyzed by inductively coupled plasma mass spectrometry (ICP-MS) at the University of Durham. Samples of $0.1 \pm 0.001 \mathrm{~g}$ were digested with $4 \mathrm{~mL}$ of $48 \%$ hydrofluoric acid and $1 \mathrm{~mL}$ of nitric acid in a Savillex bomb for $24 \mathrm{hr}$. The samples were evaporated to dryness and then taken up in $1 \mathrm{~mL}$ of nitric acid and again evaporated to dryness. A further $1 \mathrm{~mL}$ of nitric acid was added and the product again evaporated to dryness to effect quantitative removal of the hydrofluoric acid and form nitrate 
Table 1. Model mineralogy and alteration assemblage for the Leg 125 peridotites.

\begin{tabular}{|c|c|c|c|c|c|c|c|c|c|c|}
\hline \multirow[b]{2}{*}{ Rock type } & \multicolumn{5}{|c|}{ Conical Seamount } & \multicolumn{5}{|c|}{ Torishima Forearc Seamount } \\
\hline & $\begin{array}{c}\text { 778A- } \\
12 \mathrm{R}-1, \\
43-45 \mathrm{~cm} \\
\text { Harzburgite }\end{array}$ & $\begin{array}{c}779 \mathrm{~A}- \\
14 \mathrm{R}-1, \\
40-48 \mathrm{~cm} \\
\text { Harzburgite }\end{array}$ & $\begin{array}{c}779 \mathrm{~A}- \\
26 \mathrm{R}-3, \\
18-25 \mathrm{~cm} \\
\text { Harzburgite }\end{array}$ & $\begin{array}{c}780 \mathrm{C}- \\
6 \mathrm{R}-1, \\
61-62 \mathrm{~cm} \\
\text { Harzburgite }\end{array}$ & $\begin{array}{c}780 \mathrm{C}- \\
18 \mathrm{R}-1, \\
58-61 \mathrm{~cm} \\
\text { Harzburgite }\end{array}$ & $\begin{array}{c}\text { 784A- } \\
36 \mathrm{R}-1, \\
107-109 \mathrm{~cm} \\
\text { Harzburgite }\end{array}$ & $\begin{array}{c}\text { 784A- } \\
42 \mathrm{R}-1, \\
7-12 \mathrm{~cm} \\
\text { Harzburgite }\end{array}$ & $\begin{array}{l}\text { 784A- } \\
42 \mathrm{R}-1 \text {, } \\
39-41 \mathrm{~cm} \\
\text { Dunite }\end{array}$ & $\begin{array}{c}\text { 784A- } \\
\text { 45R-1, } \\
101-106 \mathrm{~cm} \\
\text { Harzburgite }\end{array}$ & $\begin{array}{c}784 \mathrm{~A}- \\
45 \mathrm{R}-1, \\
130-137 \mathrm{~cm} \\
\text { Harzburgite }\end{array}$ \\
\hline $\begin{array}{l}\text { Mode (vol\%) } \\
\text { Olivine } \\
\text { Orthopyroxene } \\
\text { Clinopyroxene } \\
\text { Spinel } \\
\text { Alteration }(\%) \\
\text { Assemblage }\end{array}$ & $\begin{array}{c}80 \\
18 \\
1 \\
1 \\
85 \\
\text { Tremolite } \\
\text { Antigorite } \\
\text { Lizardite } \\
\text { Chrysotile }\end{array}$ & $\begin{array}{c}73 \\
24 \\
2 \\
1 \\
20 \\
\text { Tremolite } \\
\text { Chrysotile } \\
\text { Lizardite }\end{array}$ & $\begin{array}{c}78 \\
19 \\
2 \\
1 \\
35 \\
\text { Lizardite } \\
\text { Chrysotile }\end{array}$ & 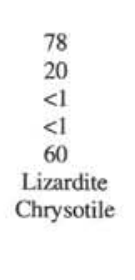 & $\begin{array}{c}76.5 \\
20 \\
1.5 \\
2 \\
70 \\
\text { Lizardite } \\
\text { Chrysotile }\end{array}$ & $\begin{array}{c}80 \\
19 \\
<1 \\
<1 \\
80 \\
\text { Lizardite } \\
\text { Chrysotile }\end{array}$ & $\begin{array}{c}99 \\
0 \\
0 \\
1 \\
90 \\
\text { Tremolite } \\
\text { Lizardite } \\
\text { Chrysotile }\end{array}$ & $\begin{array}{c}80 \\
1 \\
18 \\
1 \\
90 \\
\text { Lizardite } \\
\text { Chrysotile }\end{array}$ & $\begin{array}{c}80 \\
1 \\
18 \\
1 \\
80 \\
\text { Lizardite } \\
\text { Chrysotile }\end{array}$ & $\begin{array}{c}78 \\
1 \\
20 \\
1 \\
80 \\
\text { Lizardite } \\
\text { Chrysotile }\end{array}$ \\
\hline
\end{tabular}

salts. The samples were redissolved with $20 \mathrm{~mL}$ of deionized water and $2.5 \mathrm{~mL}$ of nitric acid and boiled for $1 \mathrm{hr}$. The cooled solutions were spiked with $1.25 \mathrm{~mL}$ of a 2-ppm $\mathrm{Rh}, \mathrm{Re}$, and $\mathrm{Bi}$ spike solution and made accurately up to $50 \mathrm{~mL}$. No undissolved spinels were detected in the Savillex bombs, and the fact that $\mathrm{Cr}$ values were comparable to those obtained by XRF suggest that all of the spinels went into solution.

The samples were run on a VG Elemental Plasmaquad with long peak dwell times ( $320 \mathrm{~ms}$ per mass unit) over the mass unit range 84 to 105 . Calibration was carried out using a set of high-Mg laboratory standards. Detection limits for $\mathrm{Ti}, \mathrm{Rb}, \mathrm{Sr}, \mathrm{Y}, \mathrm{Zr}, \mathrm{Nb}, \mathrm{La}, \mathrm{Ce}$, and $\mathrm{Yb}$ are $0.5,0.03,0.01,0.01,0.02,0.02,0.02,0.02$, and $0.02 \mathrm{ppm}$, respectively, as calculated as an average blank plus 10 standard deviations of the blank (approximately 3 times the average blank value). Precision is estimated at about $10 \%$ at 10 times the detection limit. Accuracy is better than $20 \%$ with respect to the recommended values of the USGS standard PCC-1. Detection limits for Sc, Cr, V, $\mathrm{Ni}$, and $\mathrm{Co}$ (also analyzed during the ICP-MS runs) are all less than $1 \mathrm{ppm}$, well below their concentrations in the peridotites.

Because of their very low concentrations in the Leg 125 peridotites, the REE were analyzed by isotope dilution mass spectrometry (ID-MS). The PCC-1 standard, a depleted harzburgite that also has low REE values, was included in the run to provide an independent check on the accuracy of the analyses. The analyses were conducted using a VG 354, five-collector mass spectrometer at the Department of Geology, Royal Holloway and Bedford New College, University of London. The technique is slightly modified from that devised by Thirlwall (1982) as follows.

A mixed, very dilute REE spike $(0.03 \mathrm{~g})$ was added to $0.2 \mathrm{~g}$ of sample and digested with $8 \mathrm{~mL}$ of $40 \%$ hydrofluoric and $4 \mathrm{~mL} 15 \mathrm{M}$ nitric acid in a Savillex bomb for $36 \mathrm{hr}$. The solutions were then evaporated to dryness. As found by other analyzers of ultrabasic rocks (e.g., Prinzhofer and Allègre, 1985), the chrome spinels resisted dissolution and left a small black residue in all cases. However, the chrome spinels have the lowest REE concentrations of minerals in ultramafic rocks (Stosch, 1982) and make up less than $1 \%$ of the peridotites. This residue is unlikely to have had any significant effect on the bulk-rock concentrations. The solutions were dissolved in a mixture of $75 \%$ acetic acid and $25 \% 5 \mathrm{M}$ nitric acid, centrifuged, loaded onto the first of the ion-exchange columns, washed with a mixture of $90 \%$ acetic acid and $10 \% 5 \mathrm{M}$ nitric acid, and eluted with $0.05 \mathrm{M}$ nitric acid. To remove $\mathrm{Ba}$ and other impurities, the resulting solutions were loaded onto a second set of smaller diameter columns and collected in the manner previously described. These solutions were evaporated to dryness and taken up in $1 \mathrm{~mL}$ of ultra-high-quality water. The solutions were loaded onto the two outside filaments of a Ta-Re-Ta triple-bead assembly and analyzed for REEs using a multicollector mass spectrometer (Thirlwall, 1982).
The major and trace element bulk-rock concentrations for the 10 peridotites are given in Table 2 (Sample 125-784A-45R-1, $101-106 \mathrm{~cm}$, has only mineral analyses). Our average of two analyses of the standard PCC-1 is also listed with a "recommended" analysis compiled from the major element and first-series transition element data of Govindaruju (1989), REE values of Stosch and Seck (1980), and $\mathrm{Zr}$ and $\mathrm{Nb}$ values of Jochum et al. (1990). Major element concentrations of the analyzed peridotites are an average of three XRF runs. Concentrations of first-series transition elements ( $\mathrm{Sc}, \mathrm{Ti}, \mathrm{V}, \mathrm{Cr}$, $\mathrm{Co}, \mathrm{Ni}, \mathrm{Cu}$, and $\mathrm{Zn}$ ) are an average of three XRF runs and two ICP-MS runs. There is a good correlation between the XRF and ICP-MS data. $\mathrm{The} \mathrm{Rb}, \mathrm{Sr}, \mathrm{Y}, \mathrm{Zr}$, and $\mathrm{Nb}$ values are averages of three separate ICP-MS runs. The five samples prepared aboard JOIDES Resolution (Samples 125-778A-12R-2, 43-45 cm, 125-780C-6R-1, 61-62 cm, $125-784 \mathrm{~A}-42 \mathrm{R}-1,39-41 \mathrm{~cm}, 125-780 \mathrm{C}-18 \mathrm{R}-1,58-61 \mathrm{~cm}$, and $125-$ $784 \mathrm{~A}-36 \mathrm{R}-1,107-109 \mathrm{~cm}$ ) all gave high values of $\mathrm{Nb}$ because of contamination by the tungsten-carbide tema mill, so the concentrations of this element are not reported for these samples. However, estimates of $\mathrm{Nb}$ concentrations were calculated from the $\mathrm{W}$ contamination of the samples and were used in some of the later calculations of enrichment.

The chondrite-normalized REE pattern for PCC-1 (Fig. 2) plots close to the pattern for the compiled analysis and has the same distinctive $U$ shape. Any small discrepancies between the compiled analysis and our own analysis lie well within the range of analyzed values (shaded) for the trivalent REEs and do not affect the main conclusions. We did, however, fail to reproduce the Eu value of PCC-1 in both analyses despite obtaining apparently good values on the unknown samples. The reason for this is not known.

\section{Mineral Analyses}

In-situ trace element analyses of discrete mineral phases in polished thin sections were conducted on a Cameca IMS-3f ion microprobe at Tsukuba University, Japan. Clinopyroxenes, orthopyroxenes, and olivines were chosen, mainly on the basis of freshness and size by observation under a petrographic microscope. The polished samples were evaporation-coated with gold to a thickness of approximately $20 \mathrm{~nm}$ for analysis. Measurements were made with a $10-20$-nA primary beam of mass filtered ${ }^{16} \mathrm{O}^{-}$accelerated to $14.5 \mathrm{keV}$ and focused to a spot diameter of $20 \mathrm{~mm}$ (for $\mathrm{Ti}, \mathrm{V}, \mathrm{Cr}, \mathrm{Sr}$, and $\mathrm{Zr}$ measurements) or $40 \mathrm{~mm}$ (for REE and Hf). Energy filtering of secondary positive ions was employed to eliminate isobaric molecular ion interference: secondary ions of REE and Hf were accelerated to 4.44 $\mathrm{keV}$ (energy filter of $-60 \mathrm{eV}$ ), whereas secondary ions of the other elements were accelerated to $4.41 \mathrm{keV}$ (energy filter of $-90 \mathrm{eV}$ ). The exit slit was adjusted to its maximum opening corresponding to a mass resolution $(\mathrm{m} / \Delta \mathrm{m})$ of $\sim 500$. Secondary ions were detected by a 17 - 
Table 2. Major element (\%) and trace element (ppm) concentrations in the bulk-rock peridotites.

\begin{tabular}{|c|c|c|c|c|c|c|c|c|c|}
\hline \multirow[b]{2}{*}{ Rock type } & \multicolumn{5}{|c|}{ Conical Seamount } & \multicolumn{4}{|c|}{ Torishima Forearc Seamount } \\
\hline & $\begin{array}{c}778 \mathrm{~A}- \\
12 \mathrm{R}-2, \\
43-45 \mathrm{~cm} \\
\text { Harzburgite }\end{array}$ & $\begin{array}{c}779 \mathrm{~A}- \\
14 \mathrm{R}-2, \\
40-48 \mathrm{~cm} \\
\text { Harzburgite }\end{array}$ & $\begin{array}{c}779 \mathrm{~A}- \\
26 \mathrm{R}-2, \\
18-25 \mathrm{~cm} \\
\text { Harzburgite }\end{array}$ & $\begin{array}{c}780 \mathrm{C}- \\
6 \mathrm{R}-1, \\
61-62 \mathrm{~cm} \\
\text { Harzburgite }\end{array}$ & $\begin{array}{c}780 \mathrm{C}- \\
18 \mathrm{R}-1, \\
58-61 \mathrm{~cm} \\
\text { Harzburgite }\end{array}$ & $\begin{array}{c}784 \mathrm{~A}- \\
36 \mathrm{R}-1 \\
107-109 \mathrm{~cm} \\
\text { Harzburgite }\end{array}$ & $\begin{array}{c}\text { 784A- } \\
42 \mathrm{R}-1 \\
7-12 \mathrm{~cm} \\
\text { Harzburgite }\end{array}$ & $\begin{array}{c}784 \mathrm{~A}- \\
42 \mathrm{R}-1, \\
39-41 \mathrm{~cm} \\
\text { Dunite }\end{array}$ & $\begin{array}{c}\text { 784A- } \\
45 \mathrm{R}-1, \\
130-137 \mathrm{~cm} \\
\text { Harzburgite }\end{array}$ \\
\hline $\mathrm{SiO}_{2}$ & 41.52 & 40.02 & 40.36 & 40.70 & 38.85 & 36.23 & 38.41 & 33.01 & 35.72 \\
\hline $\mathrm{TiO}_{2}$ & - & - & - & - & - & - & - & - & - \\
\hline $\mathrm{Al}_{2} \mathrm{O}_{3}$ & 0.71 & 0.78 & 0.74 & 0.47 & 0.66 & 0.27 & 0.59 & 0.20 & 0.10 \\
\hline $\mathrm{Fe}_{2} \mathrm{O}_{3}$ & 8.95 & 8.01 & 7.48 & 7.91 & 7.81 & 7.44 & 6.81 & 8.90 & 7.75 \\
\hline $\mathrm{MnO}$ & 0.08 & 0.11 & 0.11 & 0.11 & 0.11 & 0.12 & 0.10 & 0.13 & 0.11 \\
\hline $\mathrm{MgO}$ & 39.61 & 40.34 & 40.34 & 42.94 & 38.87 & 38.85 & 38.86 & 40.31 & 42.19 \\
\hline $\mathrm{CaO}$ & 0.06 & 0.47 & 0.81 & 0.60 & 0.89 & 0.06 & 0.56 & 0.14 & 0.16 \\
\hline $\mathrm{Na}_{2} \mathrm{O}$ & - & - & - & - & - & - & - & - & - \\
\hline $\mathrm{K}_{2} \mathrm{O}$ & - & - & - & - & - & - & - & - & - \\
\hline $\mathrm{P}_{2} \mathrm{O}_{5}$ & - & - & - & - & - & - & - & - & - \\
\hline $\mathrm{NiO}$ & 0.36 & 0.28 & 0.27 & 0.29 & 0.28 & 0.28 & 0.26 & 0.36 & 0.30 \\
\hline $\mathrm{Cr}_{2} \mathrm{O}_{3}$ & 0.42 & 0.74 & 0.71 & 0.24 & 0.34 & 0.16 & 0.69 & 0.27 & 0.30 \\
\hline LOI & 6.01 & 9.00 & 9.75 & 5.28 & 11.12 & 16.29 & 14.44 & 16.34 & 13.04 \\
\hline Total & 97.70 & 100.36 & 100.59 & 98.55 & 98.92 & 99.70 & 100.72 & 99.66 & 99.68 \\
\hline $\mathrm{Sc}$ & 10.65 & 10.92 & 8.28 & 8.62 & 9.47 & 6.52 & 6.96 & 3.55 & 5.10 \\
\hline $\mathrm{Ti}$ & 19.80 & 24.64 & 14.96 & 12.73 & 21.65 & 10.97 & 13.54 & 11.68 & 10.00 \\
\hline V & 46 & 33 & 34 & 27 & 40 & 22 & 22 & 14 & 13 \\
\hline $\mathrm{Cr}$ & 2866 & - & 2421 & 2249 & 2300 & 1297 & 2358 & 2380 & 1025 \\
\hline Co & 116 & - & 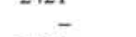 & 118 & 110 & 106 & - & 122 & - \\
\hline $\mathrm{Ni}$ & 2813 & 2127 & 2136 & 2350 & 2207 & 2214 & 2165 & 2858 & 2328 \\
\hline $\mathrm{Cu}$ & 9 & 2 & 7 & 4 & 13 & 3 & 0.5 & 3 & 1 \\
\hline $\mathrm{Zn}$ & 42 & - & - & 37 & 38 & 37 & - & 38 & - \\
\hline $\mathbf{R b}$ & 0.100 & - & - & 0.289 & 0.250 & 0.041 & 0.050 & 0.036 & 0.097 \\
\hline $\mathrm{Sr}$ & 9.17 & 0.31 & 4.47 & 2.50 & 0.05 & 2.20 & 4.48 & 4.11 & 4.32 \\
\hline $\mathrm{Y}$ & 0.078 & 0.120 & 0.071 & 0.015 & 0.100 & 0.022 & 0.020 & 0.018 & 0.021 \\
\hline $\mathrm{Zr}$ & 0.246 & - & - & 0.214 & 0.160 & 0.055 & 0.079 & 0.095 & 0.197 \\
\hline $\mathrm{Nb}$ & - & 0.022 & 0.028 & - & - & - & 0.057 & - & 0.042 \\
\hline La & 0.4866 & 0.01 & 0.04 & 0.1182 & 0.1212 & 0.0639 & 0.01 & 0.0349 & - \\
\hline $\mathrm{Ce}$ & 0.0116 & 0.01 & 0.01 & 0.0374 & 0.0067 & - & - & 0.0497 & - \\
\hline $\mathrm{Nd}$ & 0.0058 & - & - & 0.0075 & 0.0042 & 0.0071 & $\sim$ & 0.0231 & - \\
\hline Sm & 0.0014 & - & - & 0.0013 & 0.0011 & 0.0011 & - & 0.0009 & - \\
\hline $\mathrm{Eu}$ & 0.0014 & - & - & 0.0006 & 0.0003 & 0.0007 & - & 0.0003 & - \\
\hline Gd & - & - & - & 0.0015 & - & - & - & 0.0013 & - \\
\hline Dy & 0.0044 & - & - & 0.0014 & - & - & - & 0.0028 & - \\
\hline $\mathrm{Er}$ & 0.0080 & - & - & 0.0025 & 0.0157 & 0.0001 & - & 0.0080 & - \\
\hline $\mathrm{Yb}$ & 0.0229 & 0.03 & 0.03 & 0.0128 & 0.0321 & 0.0060 & 0.01 & 0.0167 & - \\
\hline Lu & 0.0054 & - & - & 0.0021 & 0.0069 & - & - & 0.0018 & - \\
\hline \multirow{3}{*}{$\begin{array}{l}\text { "Analytical } \\
\text { technique }\end{array}$} & XRF & & XRF & XRF & XRF & XRF & XRF & XRF & XRF \\
\hline & ID-MS & & & ID-MS & ID-MS & ID-MS & & ID-MS & \\
\hline & ICP-MS & ICP-MS & ICP-MS & ICP-MS & ICP-MS & ICP-MS & ICP-MS & ICP-MS & ICP-MS \\
\hline
\end{tabular}

${ }^{\text {a }} \mathrm{XRF}=\mathrm{X}$-ray fluorescence; ID-MS = isotope dilution mass spectrometry; ICP-MS = inductively coupled plasma mass spectrometry.

stage electron multiplier in pulse-counting mode and the energy bandpass of the secondary ion analyzer was adjusted to $\pm 10 \mathrm{eV}$.

Secondary ion intensities were measured for 10 to $15 \mathrm{~s}$ each on the peak tops of isotope ${ }^{30} \mathrm{Si},{ }^{51} \mathrm{~V},{ }^{52} \mathrm{Cr},{ }^{88} \mathrm{Sr},{ }^{90} \mathrm{Zr},{ }^{140} \mathrm{Ce},{ }^{146} \mathrm{Nd},{ }^{147} \mathrm{Sm}$, ${ }^{153} \mathrm{Eu},{ }^{163} \mathrm{Dy},{ }^{174} \mathrm{Yb}$, and ${ }^{180} \mathrm{Hf}$, run in ascending sequences by changing the magnetic field stepwise. The sequence was repeated 10 to 20 times per point, depending on the count rates encountered. Average elemental intensity ratios against ${ }^{30} \mathrm{Si}$ were calculated based on 10 to 20 sets of doubly time-interpolated ratios for each element at each analysis point. Concentrations determined using empirical relationships between secondary ion intensity ratios and concentration (working curves) established for mineral and glass standards are reported in Table 3. The accuracy of the concentrations reported in this paper is primarily a function of the working curves, which generally were determined to $\pm 1 \%-10 \%$ uncertainty, but are higher for Dy and Hf. The most important uncertainty in the measurements is the counting error, which, at the lower abundances encountered, can be quite high; the counting uncertainty for each element is reported in Table 3 and represents the analytical precision.

\section{EFFECTS OF ALTERATION ON TRACE ELEMENT DISTRIBUTION}

In common with all the Leg 125 peridotites, the 10 peridotites analyzed have been extensively altered, as described previously. The alteration of the Leg 125 peridotites is of two distinct types. The first and most common is the low-temperature $\left(<250^{\circ} \mathrm{C}\right)$ serpentinization in which olivine is altered to mesh-textured lizardite, orthopyroxene is altered to bastite lizardite, and many of the peridotites are cut by a complicated set of chrysotile veins. The second type is a higher temperature (approximately $600^{\circ} \mathrm{C}$ ) alteration in which olivine is replaced by bladed antigorite and orthopyroxene by tremolite and chlorite reaction rims form around many of the chrome spinels. This alteration type is less prevalent and affects only the peridotites from Conical Seamount. Girardeau and Lagabrielle (this volume) also noted that many of these samples contained thin veinlets of Ca-rich diopside and strong resorption of orthopyroxene to form fresh olivine.

Although the ultramafic rocks are commonly serpentinized, the effect of serpentinization on the trace element distribution in 
Table 2 (continued).

\begin{tabular}{|c|c|c|c|}
\hline \multirow[b]{2}{*}{ Rock type } & & & \multirow[b]{2}{*}{$\begin{array}{c}\text { Chondrite } \\
\text { value }\end{array}$} \\
\hline & $\begin{array}{c}\text { PCC-1 } \\
\text { measured } \\
\text { Harzburgite }\end{array}$ & $\begin{array}{c}\text { PCC-1 } \\
\text { compiled } \\
\text { Harzburgite }\end{array}$ & \\
\hline $\begin{array}{l}\mathrm{SiO}_{2} \\
\mathrm{TiO}_{2} \\
\mathrm{Al}_{2} \mathrm{O}_{3} \\
\mathrm{Fe}_{2} \mathrm{O}_{3} \\
\mathrm{MnO} \\
\mathrm{MgO} \\
\mathrm{CaO} \\
\mathrm{Na}_{2} \mathrm{O} \\
\mathrm{K}_{2} \mathrm{O} \\
\mathrm{P}_{2} \mathrm{O}_{5} \\
\mathrm{NiO} \mathrm{O} \\
\mathrm{Cr}_{2} \mathrm{O}_{3} \\
\mathrm{LOI}\end{array}$ & $\begin{array}{c}41.38 \\
0.01 \\
0.65 \\
8.78 \\
0.12 \\
42.9 \\
0.54 \\
0.03 \\
0.01 \\
0.01 \\
- \\
\overline{4} \\
4.91\end{array}$ & $\begin{array}{c}41.67 \\
0.013 \\
0.67 \\
8.25 \\
0.119 \\
43.43 \\
0.52 \\
0.027 \\
0.007 \\
0.002 \\
- \\
\overline{5} \\
5.12\end{array}$ & \\
\hline \multicolumn{4}{|l|}{ Total } \\
\hline $\begin{array}{l}\mathrm{Sc} \\
\mathrm{Ti} \\
\mathrm{V} \\
\mathrm{Cr} \\
\mathrm{Co} \\
\mathrm{Ni} \\
\mathrm{Cu} \\
\mathrm{Zn}\end{array}$ & $\begin{array}{r}8.47 \\
- \\
30 \\
2757 \\
111 \\
2379 \\
9 \\
49\end{array}$ & $\begin{array}{c}8.40 \\
- \\
31 \\
2730 \\
112 \\
2380 \\
10 \\
42\end{array}$ & 542.7 \\
\hline $\begin{array}{l}\mathrm{Rb} \\
\mathrm{Sr} \\
\mathrm{Y} \\
\mathrm{Zr} \\
\mathrm{Nb}\end{array}$ & $\begin{array}{l}0.070 \\
0.40 \\
0.130 \\
0.220 \\
0.030\end{array}$ & $\begin{array}{l}0.066 \\
0.40 \\
0.100 \\
0.250 \\
0.038\end{array}$ & $\begin{array}{l}0.177 \\
7.83 \\
1.985 \\
5.77 \\
0.302\end{array}$ \\
\hline $\begin{array}{l}\mathrm{La} \\
\mathrm{Ce} \\
\mathrm{Nd} \\
\mathrm{Sm} \\
\mathrm{Eu} \\
\mathrm{Gd} \\
\mathrm{Dy} \\
\mathrm{Er} \\
\mathrm{Yb} \\
\mathrm{Lu}\end{array}$ & $\begin{array}{l}0.0399 \\
0.0497 \\
0.023 \\
0.05 \\
0.007 \\
- \\
- \\
- \\
0.0217 \\
-\end{array}$ & $\begin{array}{l}0.032 \\
0.066 \\
0.033 \\
0.0058 \\
0.00096 \\
0.0068 \\
0.0096 \\
- \\
0.028 \\
0.0059\end{array}$ & $\begin{array}{l}0.310 \\
0.808 \\
0.600 \\
0.195 \\
0.0735 \\
0.259 \\
0.322 \\
0.210 \\
0.209 \\
0.0322\end{array}$ \\
\hline $\begin{array}{l}{ }^{\text {aAnalytical }} \\
\text { technique }\end{array}$ & $\begin{array}{c}\text { XRF } \\
\text { ID-MS } \\
\text { ICP-MS }\end{array}$ & & \\
\hline
\end{tabular}

ultramafic rocks is not fully understood, as no thorough investigation has been undertaken (McDonough and Frey, 1989). Empirical studies to date have failed to show any correlation between the degree of serpentinization and REE content and pattern shape (e.g., Frey et al., 1985; Prinzhofer and Allègre, 1985). Theoretically, the LREEs, Rb, and $\mathrm{Sr}$ should not be incorporated into the serpentinite (lizardite) structure, because their large ionic radii are not compatible with the octahedral sites in the serpentine (Ottonello et al., 1979). However, the elements will be mobile only if the serpentinizing fluids are able to transport them out of the system. Tatsumi et al. (1986) produced synthetic serpentine doped with selected trace elements and found that much of the La was loosely bound to the surface of the serpentine and was easily leached with $\mathrm{HCl}$. It is possible, therefore, that any LREEs released by the serpentinization process are adsorbed by the serpentine, rendering the REEs effectively immobile.

The most obvious effect of serpentinization on trace element concentrations is that of dilution resulting from the addition of water and carbon dioxide (many of the samples give between $5 \%$ and $15 \%$ loss on ignition) and, in some highly serpentinized samples, the leaching of silica. Dilution has been taken into account in this paper

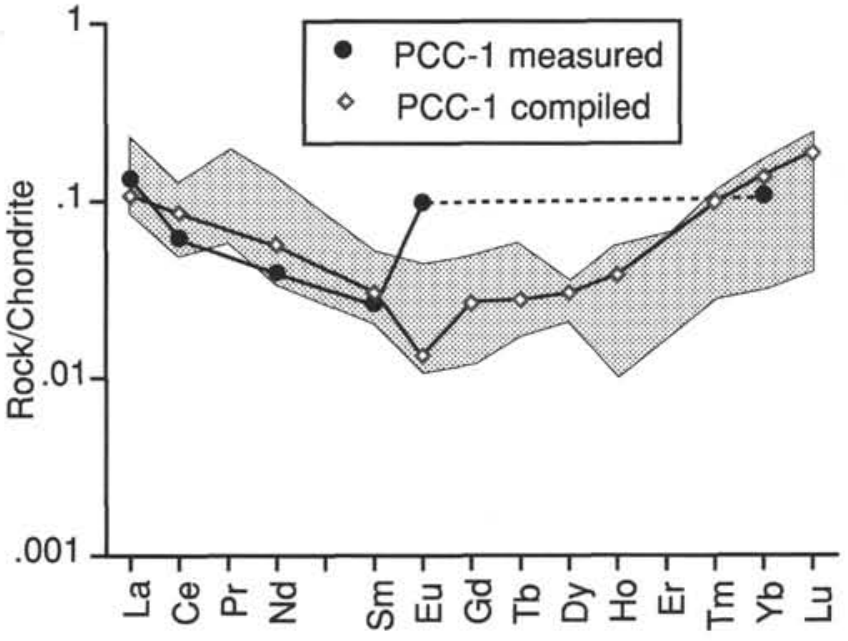

Figure 2. Chondrite-normalized REE patterns for USGS standard PCC-1 as compiled by Stosch and Seck (1980) and measured in this study. The shaded field shows the range of PCC-1 values reported in the literature as compiled by Frey (1984).

by calculating the trace element concentrations on an anhydrous basis or by using trace element ratios.

To investigate whether serpentinization has affected some of the potentially mobile trace elements other than by dilution, the ratios $\mathrm{La} / \mathrm{Yb}, \mathrm{Rb} / \mathrm{Yb}, \mathrm{Sr} / \mathrm{Yb}$, and $\mathrm{Zr} / \mathrm{Yb}$ were plotted against loss on ignition, used here as an index of degree of serpentinization (Fig. 3). Because $\mathrm{Yb}$ is less incompatible than $\mathrm{La}, \mathrm{Rb}, \mathrm{Sr}$, or $\mathrm{Zr}$, all four ratios should decrease with increasing degree of partial melting and increase with increasing degree of mantle metasomatism. Figure 3 shows that there are significant variations in these ratios, but these do not correlate significantly with loss on ignition and, hence, degree of serpentinization. There is thus no reason to assume that the observed variations are not primary. In terms of the nature of the alteration, three samples contain small amounts of the higher temperature alteration minerals tremolite and antigorite. Of these, Sample 125-778A-12R-2, $43-45 \mathrm{~cm}$, contains the most tremolite and has the highest La values, although the other two samples do not give anomalous concentrations. It is therefore possible that this type of alteration may be important in introducing LREEs into the peridotites, although this is difficult to assess from the limited number of samples analyzed.

Probably the most telling evidence that the trace element ratios studied are not affected significantly by at least the low-temperature serpentinization is the good correspondence between the trace element patterns of the bulk rocks and fresh diopsides, as discussed subsequently (Figs. 5-9).

\section{TRACE ELEMENT ENRICHMENT PATTERNS}

\section{Trace Element Characteristics of Bulk-Rock Peridotites}

Chondrite-normalized REE patterns for three harzburgites from Conical Seamount and two peridotites from Torishima Seamount are presented in Figure 4 using normalizing values published by Boynton (1984). They all define a pronounced U shape, with LREE values between 0.01 and 1.6 times chondrite, middle rare earth element (MREE) values between 0.005 and 0.01 times chondrite, and heavy rare earth element (HREE) values between 0.02 and 0.08 times chondrite. Two of the harzburgites show positive Eu anomalies of 1.7 and 2.6. Although the peridotites have very low Eu concentrations, these anomalies are larger than the errors on the Eu analyses and should therefore be real. Note, however, that we had difficulty in reproducing the Eu values in PCC-1; more work is required to confirm this result. The three peridotites from Conical Seamount have higher 


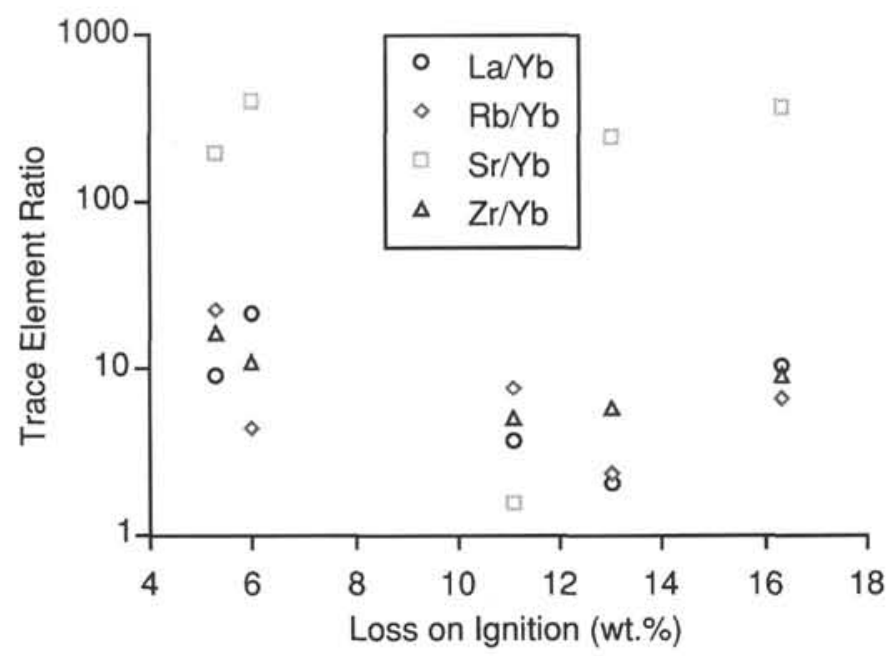

Figure 3. Plot of trace element ratios $\mathrm{La} / \mathrm{Yb}, \mathrm{Rb} / \mathrm{Yb}, \mathrm{Sr} / \mathrm{Yb}$, and $\mathrm{Zr} / \mathrm{Yb}$ against loss on ignition for the peridotites from Leg 125 shows the lack of obvious mobility during serpentinization.

La concentrations, but lower $\mathrm{Ce}$ and $\mathrm{Nd}$ concentrations, than those from Torishima Forearc Seamount. Sm concentrations are similar in all five of the samples. Also common to all samples is a trend of progressive depletion from the HREEs to the MREEs on the chondrite-normalized patterns.

Extended chondrite-normalized diagrams have been used extensively to show the trace element characteristics of both bulk-rock peridotites and their clinopyroxenes (e.g., Salters and Shimizu, 1988; Salters, 1989). Incompatible elements such as $\mathrm{Sr}, \mathrm{Zr}$, and Ti are plotted at appropriate points on the patterns so that there is a smooth decrease in incompatibility in the system peridotite melt from left to right. Conventionally, $\mathrm{Sr}$ is plotted between $\mathrm{Ce}$ and $\mathrm{Nd}, \mathrm{Zr}$ between $\mathrm{Nd}$ and $\mathrm{Sm}$, and Ti between Gd and Dy. Because not all of the elements were analyzed, the abbreviated patterns presented here are similar to those of McDonough (1991). One problem in constructing these plots is the general inconsistency between the chondrite values for the REEs and the values quoted for alkali, alkaline earth, and high-field-strength elements. This may in part be analytical and in part result from the different behavior of these elements in the fractionation and evolution of the Earth. In consequence, present-day mid-ocean ridge basalt (MORB) and MORB mantle do not give smooth patterns when published normalizing values are used. Normalizing values for $\mathrm{Rb}$, $\mathrm{Sr}, \mathrm{Y}, \mathrm{Zr}, \mathrm{Nb}$, and $\mathrm{Ti}$ were therefore adjusted so that an average N-MORB (from Sun and McDonough, 1989) plots as a smooth pattern on the diagram. The extended chondrite-normalized patterns for the peridotites from Conical and Torishima Forearc seamounts are shown in Figure 5.

It is apparent from Figure 5 that for Conical Seamount $\mathrm{Zr}$ and $\mathrm{Ti}$ give positive anomalies with respect to their adjacent REEs and two of the samples give large positive anomalies in Sr. For Torishima Forearc Seamount, both samples give positive anomalies for $\mathrm{Ti}$ and $\mathrm{Sr}$, but no $\mathrm{Zr}$ anomaly is apparent. $\mathrm{Y}$ gives no anomaly, as would be expected from its similar charge and radius to the adjacent REEs. Rb also shows no anomaly with respect to $\mathrm{La}$.

It is, however, also important to note that anomalies can be created on this conventional projection by partial melting alone. We have illustrated this effect in Figure 6. Figure 6A shows theoretical extended chondrite-normalized patterns for peridotites that represent residues from different degrees of partial melting of a MORB mantle source. The modeled values are based on incremental melting $(0.1 \%$ steps), assuming that clinopyroxene disappears after $25 \%$ melting and using the mineral/liquid distribution coefficients of Kelemen et al.
(1990). Details of this model are given in the Appendix. It can be seen that positive $\mathrm{Zr}$ and $\mathrm{Ti}$ anomalies are developed as the degree of partial melting increases. Sr also gives a positive anomaly at very high degrees of melting, off scale on this diagram.

To determine an order for the elements that will be independent of the degree of partial melting, and hence enable us to view trace element enrichments of the mantle source, we plotted the variations in the bulk distribution coefficients for residues of melting of a MORB source as a function of degree of partial melting (Fig. 6B). It is apparent that the REEs behave coherently during partial melting, plotting as subparallel lines. By contrast, $\mathrm{Sr}, \mathrm{Zr}$, and $\mathrm{Ti}$ form trends that cross the REE lines, indicating that their similarity to a given REE depends on the degree of melting. Although it can be argued that the precise behavior of these elements will depend on the point of disappearance of clinopyroxene and the partition coefficients chosen, all three elements must experience a shift in behavior toward the heavier REEs as melting proceeds. Thus, although the order adopted by Salters and Shimizu (1988) is correct for fertile peridotites, the order must be changed in considering the depleted peridotites from Leg 125 .

To plot the most appropriate order, it is necessary to estimate the degree of melting experienced by the Leg 125 peridotites. Ishii and Robinson (this volume) used the $\mathrm{CaO}$ and $\mathrm{Al}_{2} \mathrm{O}_{3}$ contents of the peridotites to make this estimate. These oxides are progressively depleted as melting proceeds and their concentrations have been calibrated for the degree of partial melting by Ishiwatari (1985) using the equilibrium melting experiments of Jaques and Green (1980). Ishii and Robinson (this volume) obtained degrees of melting in the range of $25 \%-33 \%$ using this method. These will be maximum values because the experiments simulated equilibrium melting. Incremental or fractional melting, which best fits the Leg 125 peridotite data, would cause the observed, low $\mathrm{CaO}$ and $\mathrm{Al}_{2} \mathrm{O}_{3}$ contents to be reached with less partial melting, because both these elements are incompatible during melting. A better estimate of the degree of melting may therefore lie in the range of $20 \%-25 \%$ (Pearce et al., chapter 38, this volume). At these values, according to Figure $6 \mathrm{~B}$, Ti should be plotted between $\mathrm{Er}$ and $\mathrm{Yb}$ or even beyond $\mathrm{Yb}, \mathrm{Sr}$ should be plotted between $\mathrm{Nd}$ and $\mathrm{Sm}$, and $\mathrm{Zr}$ should be plotted between $\mathrm{Eu}$ and $\mathrm{Gd}$.

Figure 7 is the same extended chondrite-normalized plot as Figure 5, but with the elements plotted in their correct positions for depleted peridotites. Note that the interpretation of the $\mathrm{Sr}$ anomalies does not change, although the size of the anomaly is increased in some samples. However, the HFSEs, $\mathrm{Ti}$ and $\mathrm{Zr}$, are markedly affected. $\mathrm{Zr}$ now shows positive anomalies in all samples whereas $\mathrm{Ti}$ shows no positive anomaly at all and in some samples gives a negative anomaly. Given that an unenriched abyssal peridotite would show a pattern that decreased constantly from the HREEs to the LREEs, a first-order interpretation of these patterns is that the peridotites have been enriched in LREEs, $\mathrm{Rb}, \mathrm{Sr}, \mathrm{Zr}$, and Eu relative to $\mathrm{Ti}$ and the trivalent MREEs and HREEs.

\section{Trace Element Characteristics of Clinopyroxenes}

In-situ trace element analyses of clinopyroxene, orthopyroxene, and olivine are presented for five of the peridotites in Table 3 . Chondritenormalized REE plots of clinopyroxenes from the five peridotites are presented in Figure 8. The field for clinopyroxenes from the most depleted abyssal peridotites analyzed by Johnson et al. (1990) is also plotted for comparison. In accordance with the depleted major and trace element chemistry of the peridotites, the diopsides in the Leg 125 peridotites have very low REE contents. They have flat to humped HREE to MREE patterns similar to patterns for diopsides from abyssal peridotites not associated with hot spots. With the exception of Sample 125-784A-42R-1, 7-12 cm, all the diopsides show a marked upward inflection in Ce relative to $\mathrm{Nd}$. The diopsides from the Leg 125 peridotites have lower HREE contents than diopsides from the most depleted abyssal 

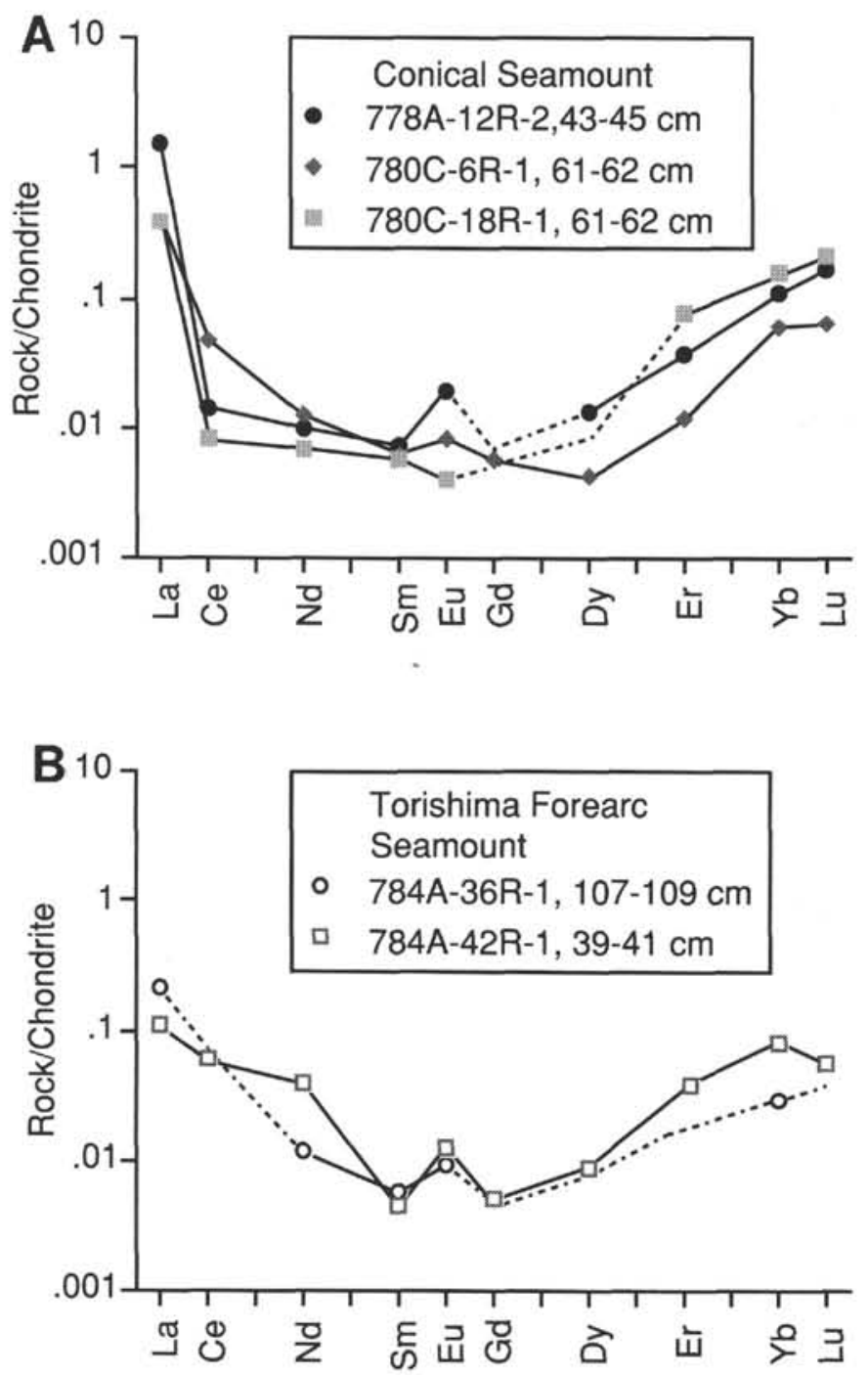

Figure 4. Chondrite-normalized REE patterns of peridotites from (A) Conical Seamount and (B) Torishima Forearc Seamount. Sample 125-784A-42R-1, $39-41 \mathrm{~cm}$, is a dunite.

peridotites reported in Johnson et al. (1990), but have less fractionated REEs, with $(\mathrm{Ce} / \mathrm{Yb})_{n}$ ratios of $0.018-0.15$ compared with $(\mathrm{Ce} / \mathrm{Yb})_{n}$ ratios of $0.002-0.05$ in abyssal peridotites.

Of the other elements, $\mathrm{Sr}$ concentrations in the diopsides range from 0.43 to $5.19 \mathrm{ppm}$ and are high compared with $\mathrm{Sr}$ values in diopsides from abyssal peridotites with a similar proportion of modal clinopyroxene. $\mathrm{Zr}$ and Ti have very low concentrations, between 0.17 and $0.39 \mathrm{ppm}$ and between 105 and $156 \mathrm{ppm}$, respectively. However, the Leg 125 peridotites have less fractionated Ti/Zr ratios than abyssal peridotites (300-750 compared with $250-4000$ ). To plot diopsides from the Leg 125 peridotites on extended chondrite-normalized plots (Fig. 9) it was again necessary to change the order from that proposed by Salters and Shimizu (1988), because the order should take into account compatibility in the system diopside melt as well as peridotite melt. To do this, and to eliminate the apparent negative anomalies in abyssal peridotite patterns, it was necessary to plot $\mathrm{Sr}$ to the left of $\mathrm{Ce}, \mathrm{Zr}$ between $\mathrm{Ce}$ and $\mathrm{Nd}$, and $\mathrm{Ti}$ between $\mathrm{Eu}$ and $\mathrm{Sm}$ (i.e., to use the order of compatibility with respect to diopside.

The HFSEs, Ti and Zr, commonly show marked depletions with respect to their neighboring REEs in diopsides to the extent that
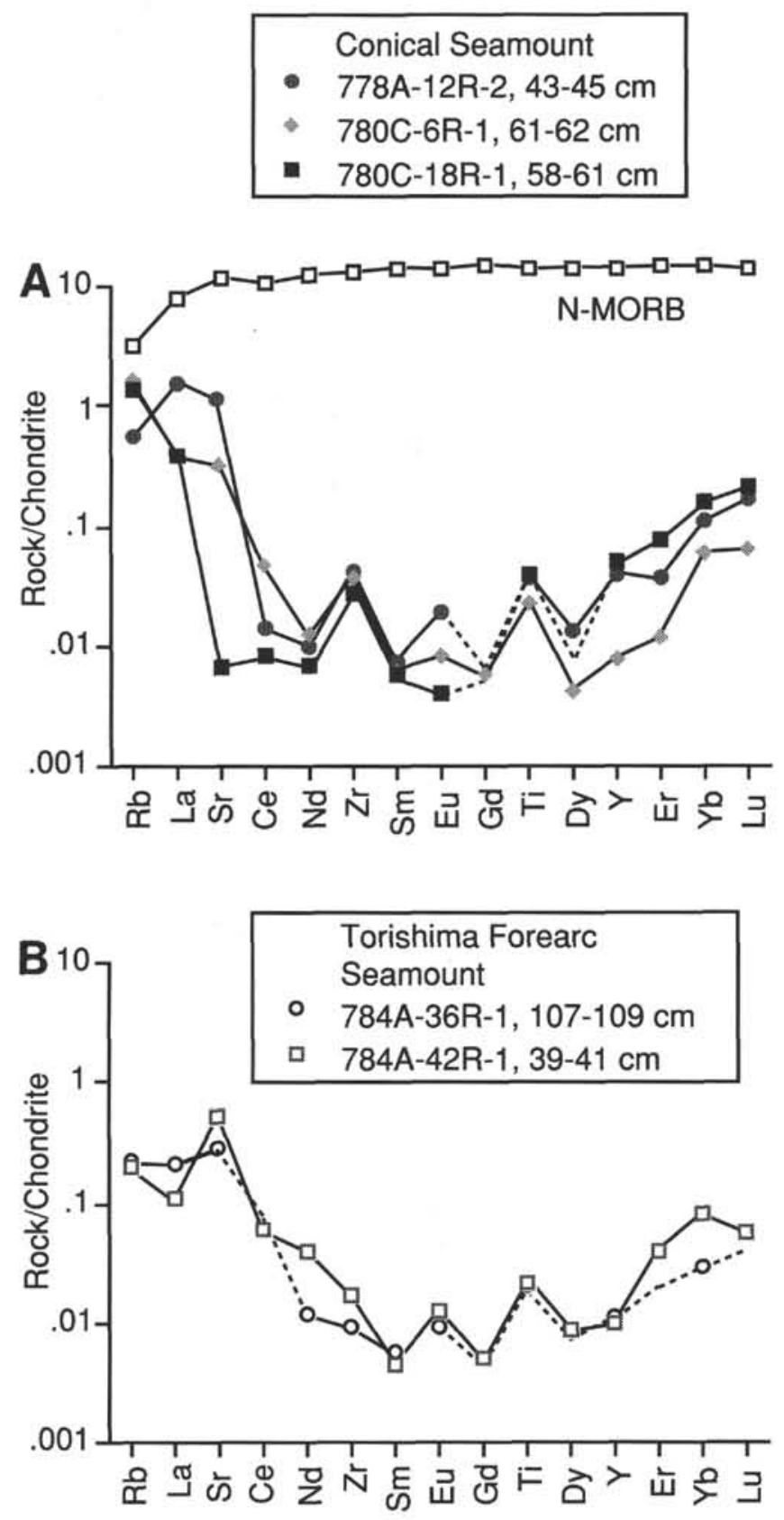

Figure 5. Chondrite-normalized extended REE patterns of peridotites from (A) Conical Seamount and (B) Torishima Forearc Seamount. Element ordering is for a fertile peridotite as discussed in the text. The pattern for an average N-MORB is from Sun and McDonough (1989).

Salters and Shimizu (1988) suggested that there is a global HFSEdepleted shallow upper mantle. However, the revised plot order removes these anomalies for abyssal peridotites.

In summary, REE, $\mathrm{Zr}$, Ti, Hf, and $\mathrm{Sr}$ concentrations in the diopsides from the Leg 125 peridotites are markedly different from the concentrations of these elements in abyssal peridotites (e.g., Salters and Shimizu, 1988; Johnson et al., 1990). They are characterized, in particular, by very low concentrations of trace elements, but by marked enrichments in the LREEs, $\mathrm{Rb}, \mathrm{Sr}$, and $\mathrm{Zr}$ relative to $\mathrm{Ti}$ and the MREEs to HREEs. 

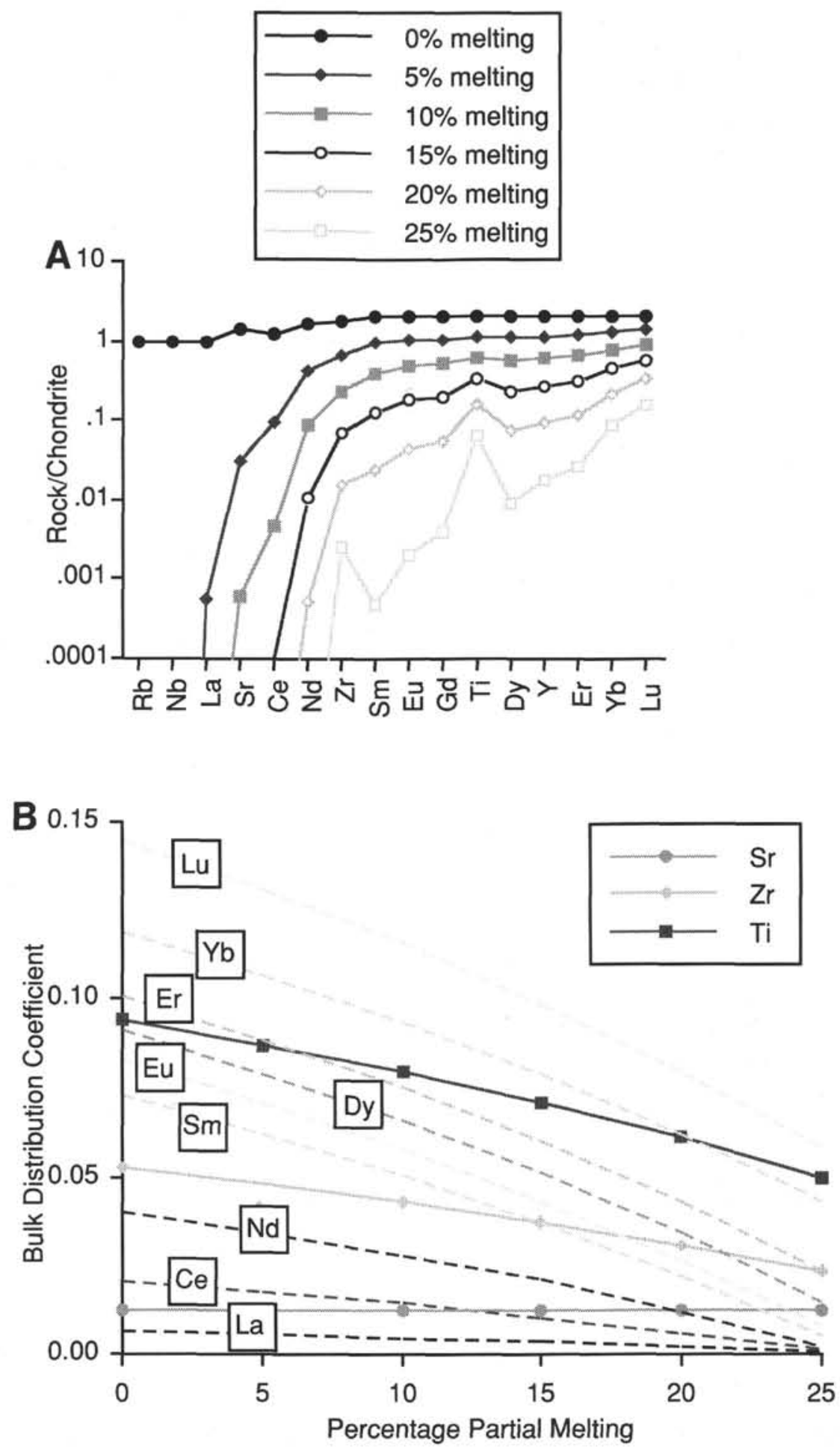

Figure 6. A. Chondrite-normalized extended REE patterns of modeled peridotites after $0 \%-25 \%$ partial melting. $\mathrm{Zr}$ and $\mathrm{Ti}$ positive anomalies are produced with increasing degree of partial melting. Sr shows a similar positive anomaly at $20 \%-25 \%$ partial melting, but is not shown for clarity. B. Plot of bulk distribution coefficients against percentage partial melting for REE, $\mathrm{Sr}, \mathrm{Zr}$, and Ti. The REE behave coherently, whereas $\mathrm{Sr}, \mathrm{Zr}$, and $\mathrm{Ti}$ cross the REE lines with increasing percentage partial melting. Modeling parameters for both diagrams are given in the Appendix. 

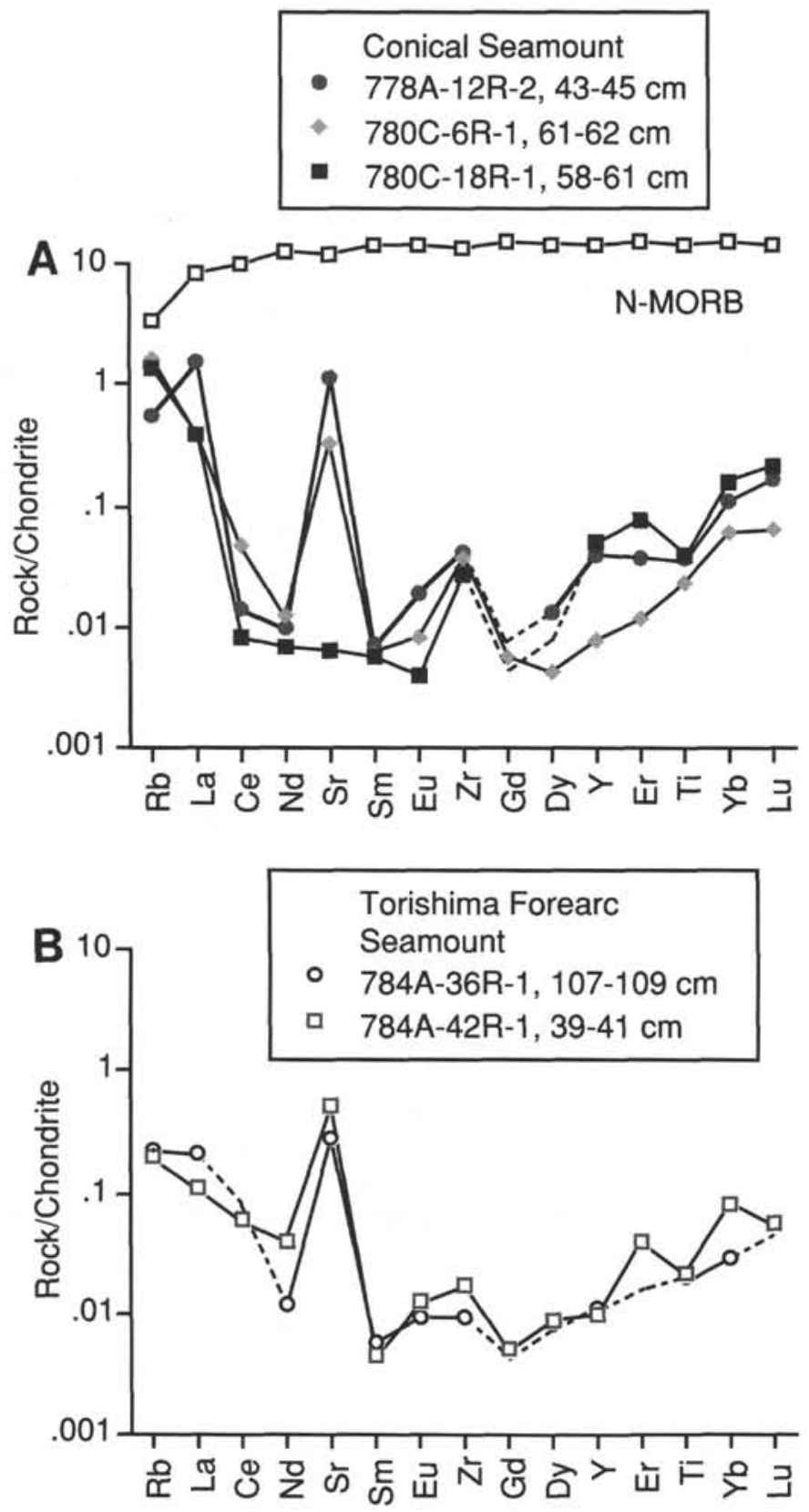

Figure 7. Chondrite-normalized extended REE patterns of peridotites from (A) Conical Seamount and (B) Torishima Forearc Seamount. Element ordering is for a harzburgite mantle as discussed in the text. The pattern for an average N-MORB is from Sun and McDonough (1989).

\section{NATURE AND TIMING OF TRACE ELEMENT ENRICHMENTS}

The extended chondrite-normalized patterns provided compelling evidence for LREE, $\mathrm{Sr}$, and $\mathrm{Zr}$ enrichment relative to $\mathrm{Ti}$ and the MREEs-HREEs in the Leg 125 peridotites and their constituent minerals. The extent of the enrichment can be determined for a given peridotite by (1) estimating the composition that peridotites would have had if this enrichment process had not taken place and (2) comparing this with the observed composition. The preenrichment composition can be determined empirically by identifying an unenriched sample with the necessary characteristics or theoretically by assuming a fertile mantle composition and its melting history. To produce a complete model, it is also important to determine whether this enrichment took place before, during, or after partial melting. Because there are more trace element data on clinopyroxenes from depleted abyssal peridotites than on whole rocks, the clinopyroxenes provide the best opportunity to adopt the empirical approach. The bulk rocks, however, provide a measure of the overall enrichment. We therefore examine the clinopyroxene data, followed by the bulkrock data.

\section{Extent of LREE, Zr, and Sr Enrichment from the Peridotite Clinopyroxenes}

The extent of trace element enrichments can be examined by plotting a series of elements against the element thought to have been least affected by the enrichment process. Figure 7 shows that $\mathrm{Ti}$ and the HREEs best satisfy the latter criteria. $\mathrm{Yb}$ is plotted against $\mathrm{Ti}$ in Figure 10. To "calibrate" the diagram, the abyssal peridotite data of Johnson et al. (1990) and the Ronda peridotite data of Salters and Shimizu (1988) were also plotted and annotated according to the modal content of clinopyroxene in the samples. They form a trend from an estimated MORB mantle composition within the field of the Ronda peridotites to the most depleted abyssal peridotite with about $200 \mathrm{ppm}$ Ti. The predicted clinopyroxene compositions for fractional, incremental, and equilibrium melting models are also plotted, using the parameters given in the Appendix. Three models are used because the precise nature of mantle melting is still poorly understood. Fractional melting is the most effective at depleting the residual solids in incompatible elements whereas batch equilibrium is the least effective. Incremental batch melting is intermediate to these two extremes: the smaller the increment, the closer the model to fractional melting. Note that, as pointed out by Johnson et al. (1990), equilibrium batch melting cannot produce the low concentrations of $\mathrm{Yb}$ and Ti observed in the clinopyroxenes. An incremental melting trend, based on small melt increments, or fractional melting best correlates with the degree of melting estimated from the clinopyroxene content.

Figure 10 shows that the Leg 125 peridotites plot on an extension of the observed and modeled depletion trends, below even the most deleted abyssal peridotites. This provides further evidence that the Leg 125 peridotites are residues from extensive melting. As the diagram is calibrated, they would correspond to $20 \%-25 \%$ partial melting compared with $15 \%-20 \%$ for the most depleted abyssal peridotite clinopyroxene analyzed by Johnson et al. (1990). The fact that the peridotites lie on a direct extension of the abyssal peridotite trend has a number of implications. First, it suggests that the Leg 125 peridotites can be considered residues from melting, in one or more stages, of a MORB source. Second, it confirms that neither Ti nor Yb was affected significantly by the same event that enriched the peridotites in LREEs, $\mathrm{Sr}$, and $\mathrm{Zr}$. It is, of course, possible that these elements were enriched, but in similar degrees and to an extent that they continued to fall on the abyssal peridotite trend within the limits of experimental error. It is, however, unlikely that any enrichment was of major significance as the samples plot well below the abyssal peridotite field in a position consistent with their inferred high degree of melting. We shall assume here that neither element was significantly enriched.

Figure 11 shows plots of $\mathrm{Sr}, \mathrm{Ce}, \mathrm{Nd}, \mathrm{Zr}, \mathrm{Sm}, \mathrm{Eu}$, and Dy against Ti, where $\mathrm{Ti}$ rather than $\mathrm{Yb}$ is used as the unenriched element because of its considerably better counting precision. It can be seen that Dy plots at the end of the depletion trend defined by the abyssal peridotites, and thus also is inferred not to have been enriched in the host peridotites. By contrast, the elements $\mathrm{Eu}, \mathrm{Sm}, \mathrm{Nd}, \mathrm{Ce}, \mathrm{Zr}$, and $\mathrm{Sr}$ are displaced to higher values than would be expected for the abyssal peridotite depletion trend, confirming that these elements have been added to the peridotites at some stage in their history. The extent of the enrichment can easily be determined because the preenrichment composition can be read off the $\mathrm{Yb}-\mathrm{Ti}$ diagram in Figure 10. The scatter in abyssal peridotites for some elements is probably the result of reenrichment by melts or of the location of some of the samples at ridges adjacent to hot spots. However, it is still apparent that the degree of enrichment in the Leg 125 peridotites increases in the 

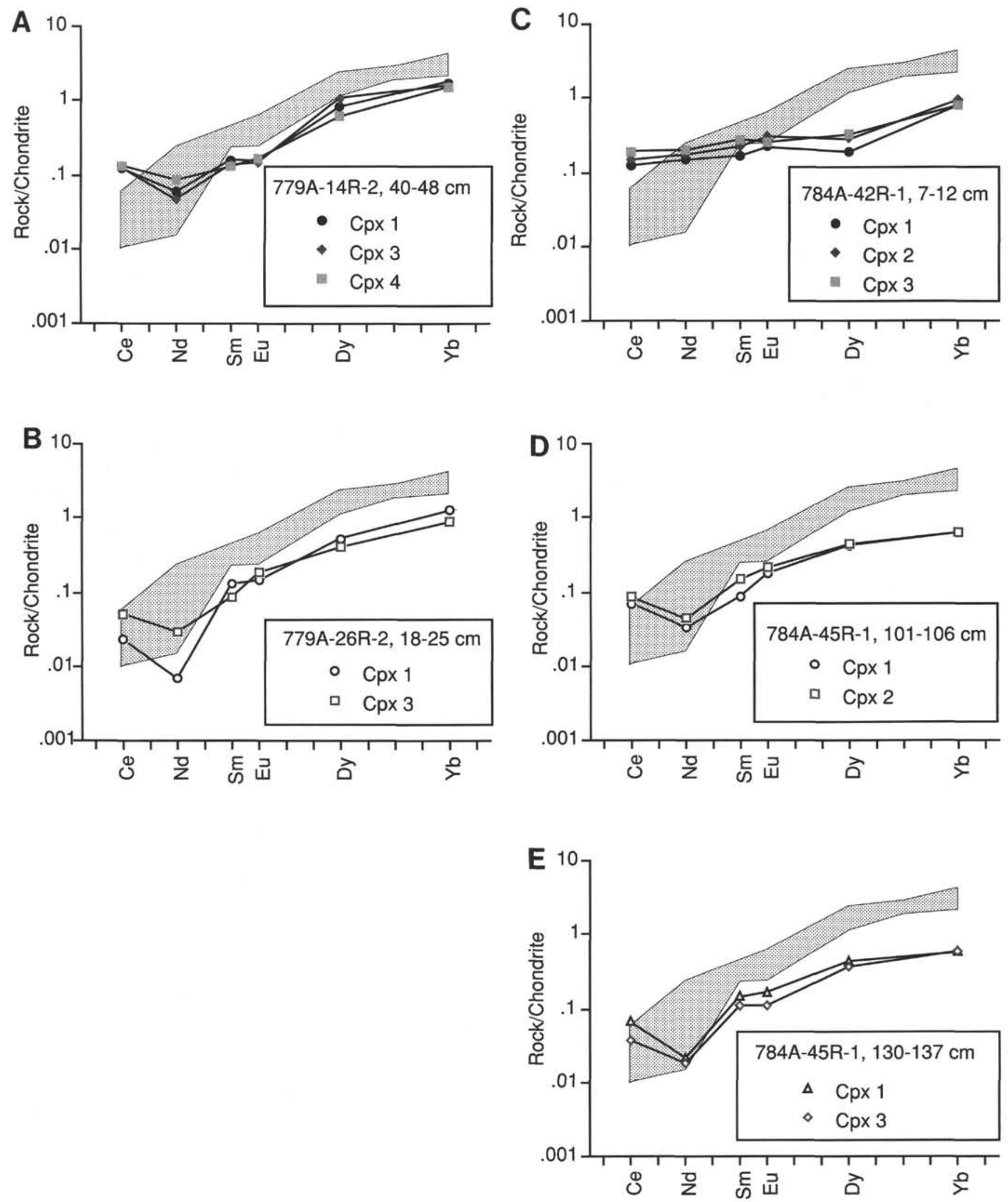

Figure 8. Chondrite-normalized REE patterns of clinopyroxenes from (A and B) Conical Seamount and (C-E) Torishima Forearc Seamount. The shaded field represents the most depleted abyssal peridotites from Johnson et al. (1990). 

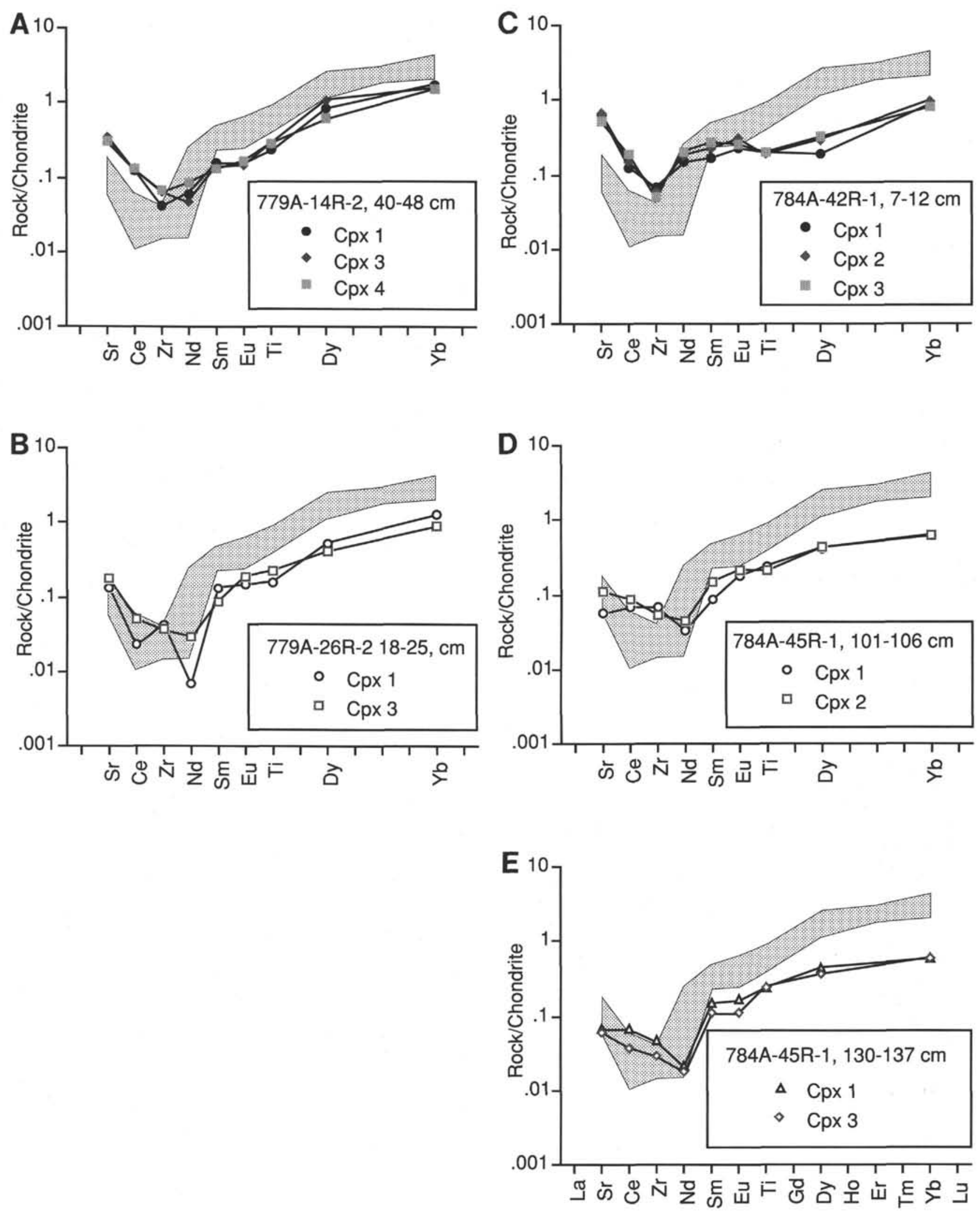

Figure 9. Chondrite-normalized extended REE patterns of clinopyroxenes from (A and B) Conical Seamount and (C-E) Torishima Forearc Seamount. The shaded field represents the most depleted abyssal peridotites from Johnson et al. (1990). The element order is based on clinopyroxene/liquid distribution coefficients as discussed in the text. 


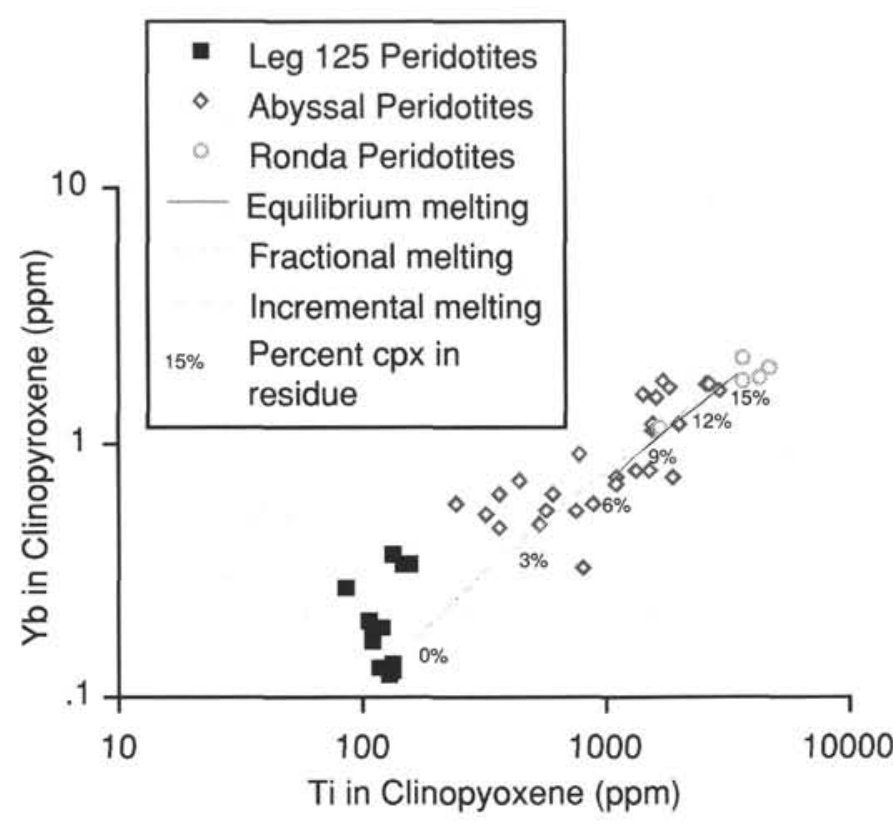

Figure 10. Ti vs. Yb concentrations in clinopyroxenes from Leg 125, abyssal, and Ronda peridotites. The three lines representing forward-modeled equilibrium, fractional, and incremental $(0.1 \%$ increments) residual clinopyroxene compositions show that equilibrium melting cannot produce the observed concentrations in the clinopyroxenes, whereas the fractional or incremental models closely match the clinopyroxene compositions. The incremental melting line was calibrated with percentage clinopyroxene in the modeled residue. The reasons for the small discrepancy between the proportions of modeled and observed clinopyroxene are discussed in the text.

order Eu, Sm, Nd, Zr, Ce, and Sr. These proportions need not, of course, correlate precisely with the whole-rock enrichment, because olivine and orthopyroxene may show different enrichment patterns and because of possible incorporation into, and adsorption onto, alteration minerals.

The Ce-Ti, Sr-Ti, Nd-Ti, and Zr-Ti diagrams in Figure 11 also constrain the timing of the enrichment episode. The fact that the principal axis of dispersion for the Leg 125 peridotites lies in the direction of the enriched element (i.e., variable $\mathrm{Ce}, \mathrm{Sr}, \mathrm{Nd}$, and $\mathrm{Zr}$ for almost constant $\mathrm{Ti}$ ) can be explained most simply in terms of variable enrichment during and after melting. It can be argued that enrichment took place before the second melting event after the extraction of MORB. However, for enrichment to predate melting, largemagnitude (up to 10 times), small-scale heterogeneities would have to have been present in the peridotite before melting and have persisted during the melting episode. This is unlikely because diffusion rates should be sufficiently high to "smooth out" such heterogeneity during the ascent and partial melting of a mantle diapir. We therefore conclude that the diopsides equilibrated with a fluid during melting and, probably, under subsolidus conditions following melting. This theme is reexamined later in this paper.

\section{Extent of LREE, Zr, and Sr Enrichment from Bulk-Rock Peridotites}

As shown in the previous section the clinopyroxenes are enriched in $\mathrm{Sr}$, LREEs, and $\mathrm{Zr}$ relative to the MREEs-HREEs and Ti. The extent of these enrichments in the bulk rock can be determined for a given peridotite by comparison with an abyssal peridotite that has undergone an equivalent degree of partial melting. However, no abyssal peridotite is sufficiently depleted to provide a potential preenrichment composition. Forward modeling of mantle melting of a fertile abyssal peridotite was therefore used to estimate this composition. To constrain the forward modeling, it was necessary to use one or more of the incompatible elements that have not been enriched in the peridotites to gauge of the degree of depletion of the peridotite. As before, Ti and the HREEs were used for this purpose.

It was shown from the clinopyroxene modeling that incremental melting based on very small melt increments best simulates the abyssal peridotite depletion trend. This was used in modeling the extended REE patterns in Figure 6. The pattern for $25 \%$ melting gives a close match with the values of $\mathrm{Ti}$ and the HREEs and is therefore used as the unenriched composition. It should be noted that at $25 \%$ melting the modeled peridotites have no clinopyroxene, whereas the Leg 125 peridotites have $1 \%$. Also, it is not possible to get sufficiently low $\mathrm{Ti}$ concentrations using a $\mathrm{Ti}$ clinopyroxene/liquid distribution coefficient of 0.3 . Modeled values give $30 \mathrm{ppm}$ after $25 \%$ fractional melting, whereas the whole rocks have $10-23 \mathrm{ppm}$. This could be counteracted by lowering the $K_{d}$ of $\mathrm{Ti}$ nearer to 0.25 or by having clinopyroxene melting out at nearer $30 \%$ or a combination of the two. Because of the lack of data on the pressure, temperature, and compositional dependence of the $K_{d}$ values we used the compiled list of $K_{d}$ values of Kelemen et al. (1990) so that the Ti distribution coefficients are consistent with the REEs and other trace elements. This does not affect later calculations on the elements that are enriched.

Figure 12A contrasts a typical pattern for the Leg 125 peridotites with the modeled pattern for the preenrichment composition. One of the consequences of using incremental or fractional melting models is that the highly incompatible elements $\mathrm{La}, \mathrm{Nb}$, and $\mathrm{Rb}$, and to a slightly lesser extent $\mathrm{Ce}, \mathrm{Sr}$, and $\mathrm{Nd}$, are depleted very rapidly in the residues and tend to zero in the preenrichment composition at the high degrees of melting required to produce the Leg 125 peridotites. An estimate of the relative amounts of enrichment of the trace elements can be made by using the mass-balance equation to calculate the difference between the concentration in the modeled residues and the amount measured in the actual rock (Fig. 12B). The patterns drawn assume that the mass fraction of the enriching component is $1 \%$. Deviations from this value affect the level of the pattern but have little effect on the pattern shape. It can be seen that virtually all the measured concentrations of $\mathrm{Rb}, \mathrm{Nb}, \mathrm{La}$, $\mathrm{Ce}$, and $\mathrm{Sr}$ were introduced in the enrichment component. Using the same argument, up to $90 \%$ of $\mathrm{Zr}, \mathrm{Sm}$, and Eu must have been added. $\mathrm{Ti}$, by definition, exhibits no enrichment but there may have been a small enrichment of the HREEs.

Several factors affect the detail of this model. Different melting models will give different enrichment factors. Essentially, the smaller the increments in an incremental melting model, the greater the depletion of the incompatible elements in the preenrichment composition and the greater the enrichment determined from the diagram. The method also assumes an average MORB source. The more enriched that a source is relative to MORB, the lower the apparent enrichments. Similarly, the lower the $K_{d}$, the greater the apparent enrichment. Furthermore, it is possible, as discussed earlier, that all the MREEs-HREEs were slightly enriched. Note, however, that none of these variables greatly influences the overall pattern of trace element enrichment.

A final caveat is that although we believe that the peridotites require an episode of LREE enrichment, Prinzhofer and Allègre (1985) proposed that it is possible to generate a U-shaped pattern by a melting process only. They successfully modeled U-shaped REE patterns from a slightly LREE-depleted source by "sequential integrated disequilibria" melting in the garnet, spinel, and plagioclase lherzolite fields. However, the LREE enrichment of the peridotites in their model relies heavily on LREE-enriched mineral/melt coefficients for olivine, which are open to doubt (Frey, 1984). Moreover, ion microprobe analyses of residual clinopyroxenes from abyssal peridotites (Johnson et al., 1989) clearly demonstrate a relationship between the proportion of residual clinopyroxene and the clinopyroxene composition. This observation is inconsistent with disequilibrium melting, which requires that residual minerals retain their original composition during melting. We therefore concur with the consensus view, that U-shaped REE patterns in the peridotites result from enrichment in an LREE-rich component. 

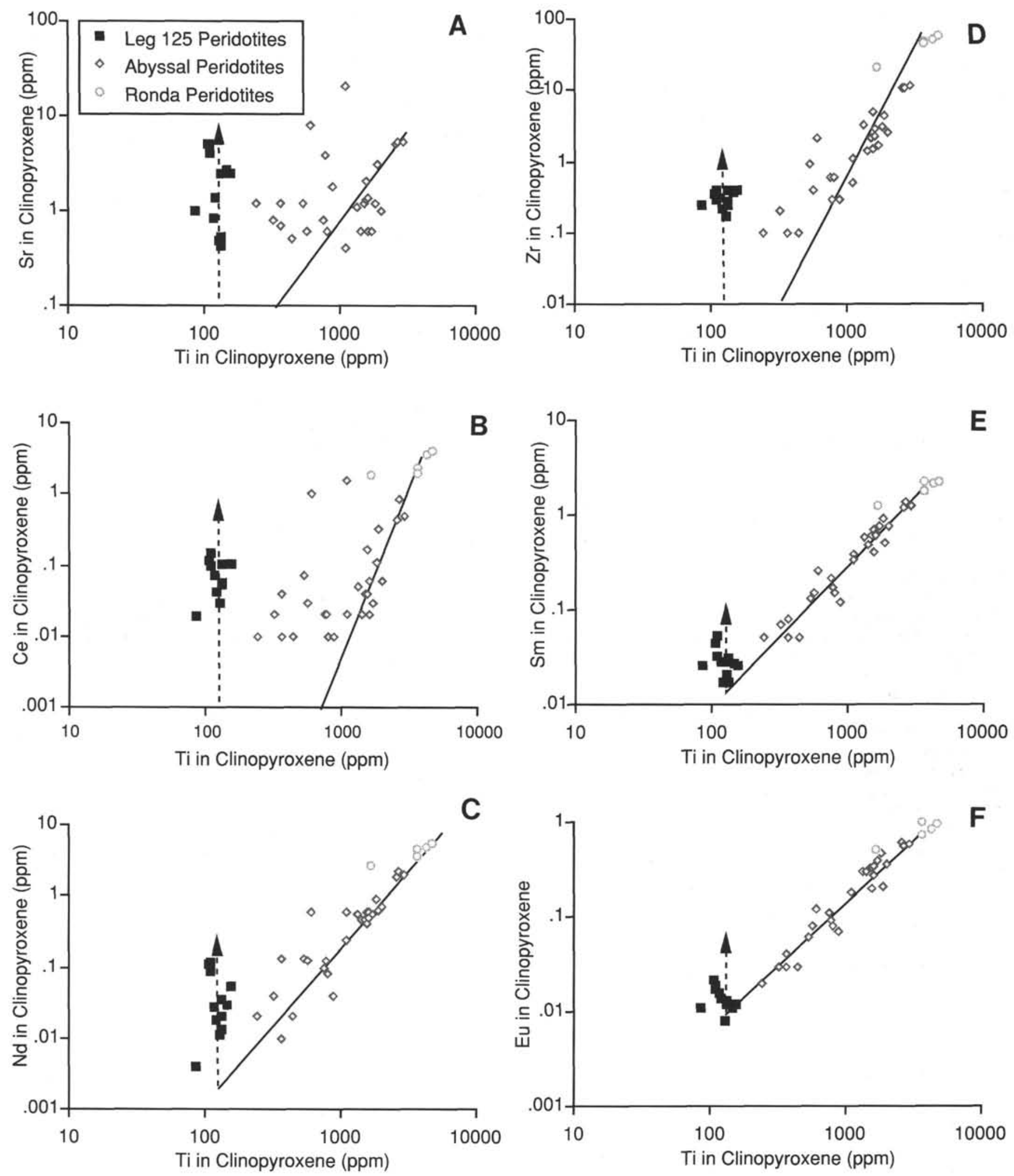

Figure 11. Ti concentration in clinopyroxenes vs. $\mathrm{Sr}, \mathrm{Ce}, \mathrm{Nd}, \mathrm{Zr}, \mathrm{Sm}, \mathrm{Eu}$, and Dy for Leg 125, abyssal, and Ronda peridotites. The solid line in each plot represents the depletion trend shown by the abyssal peridotites and the dotted line represents the trend of enrichment for the Leg 125 peridotites. Note how enrichment is shown by a variable increase in the elements at nearly constant $\mathrm{Ti}$ concentrations. 


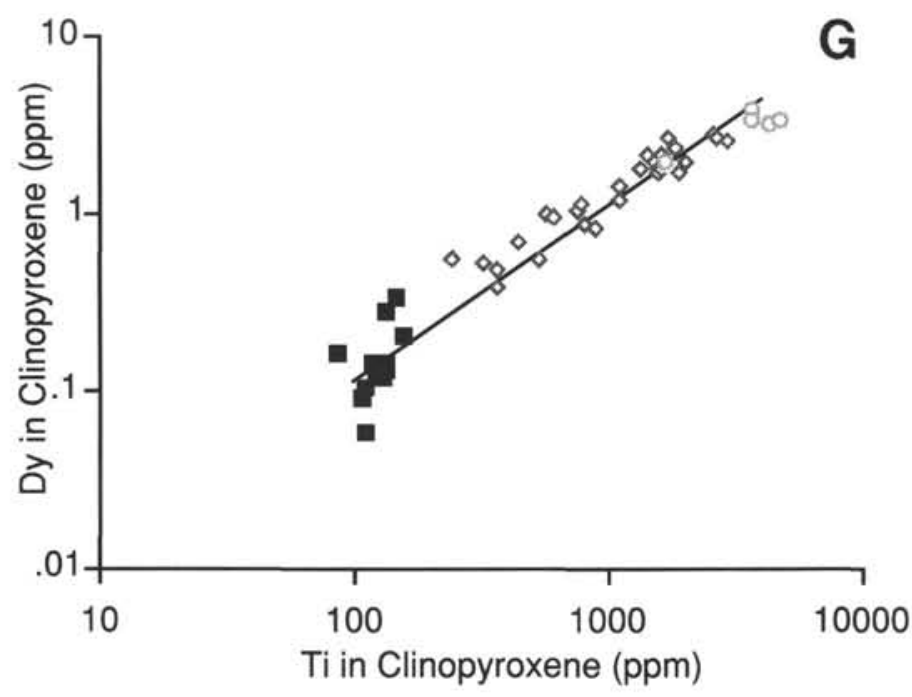

Figure 11 (continued).

\section{CAUSES OF LREE, Zr, AND Sr ENRICHMENT}

There are three possible sources of the enrichment in the peridotites: small melt fractions and $\mathrm{CO}_{2}$-rich fluids from the asthenosphere, melt fractions and related hot aqueous fluids from the subduction zone, and low-temperature fluids that cause serpentinization. Because the aqueous fluids that serpentinized the peridotites may have a slab-derived component (Leg 125 Shipboard Scientific Party, 1989; Sakai et al., 1990) it is feasible that the latter two enrichment processes are strongly interrelated.

Time-integrated enrichment of the lithosphere by small-degree asthenospheric fluids is a common cause of metasomatic enrichment in peridotites (e.g., Frey and Green, 1974; McKenzie, 1989). Many scientists have suggested that the source of forearc boninites was oceanic lithosphere metasomatized by these fluids, the so-called "OIB (ocean island basalt) component" (see references in Crawford, 1989). A principal characteristic of this component is that the enrichment of a given element is a function of its incompatibility with respect to garnet lherzolite. As a result, the OIB components typically exhibit a marked enrichment of the MREEs with respect to the HREEs. Nb is also strongly enriched, perhaps even more than $\mathrm{La}$. The enrichment pattern in Figure 12B shows that neither characteristic is a feature of the Leg 125 peridotites, which would be marked by a steady increase in enrichment level from right to left within the pattern. Moreover, Figure 11 indicates that enrichment did not predate the melting event. Thus, it is unlikely that "normal" astheno- spheric fluids were the cause of this enrichment. This conclusion supports the isotopic evidence from the boninites, that none of the isotopic components involved in the enrichment of the boninite source had the composition of asthenospheric fluids of the OIB type (Pearce et al., chapter 38, this volume).

It is, nonetheless, possible that an asthenospheric melt did invade the peridotites during or after melting if its composition had been fractionated en route. Navon and Stolper (1987) suggested that the composition of a fluid percolating through the mantle could be fractionated by the chromatographic column effect. In this model, elements travel with a velocity related to their distribution coefficients with respect to the surrounding mantle. The more incompatible elements will move with a faster effective velocity than the more compatible elements. In an amphibole-bearing mantle wedge, elements compatible with amphibole (such as $\mathrm{Ti}$ and the MREEsHREEs) will be held back and the resultant melt component could resemble the enrichment component seen in the peridotites. The effect of this fractionation will have a transient effect on the peridotites in the mantle wedge as the peridotites will eventually have a chance to equilibrate with all the fluid that has passed through the wedge. Equilibration with the peridotites in the mantle wedge depends on the time scale of the percolation and the content of the fluid.

Alternatively, the enrichment may be derived entirely from the subducted slab. Melted or dehydrated subducted sediments may be the dominant source of subduction components in the BoninMariana region at the present. Lead isotopes show that fluids and melts from subducted sediment were also involved in the genesis of Eocene lavas from Chichi-Jima (Dobson and Tilton, 1989) and that subducted sediments contribute to the genesis of active arc volcanoes in the Mariana region (Woodhead, 1989). The sediment component does not, however, explain the HFSE enrichment seen in the Leg 125 peridotites. A partial melt of amphibolite derived from the subducted slab has also been invoked as a way of explaining the isotope systematics in the Leg 125 (and other) boninites (Pearce et al., chapter 38, this volume). This component explains the absence of a displacement toward a pelagic sediment field on $\mathrm{Pb}$ isotope diagrams and the selective enrichment of elements not retained in the residual amphibole (e.g., $\mathrm{La}, \mathrm{Ce}, \mathrm{Zr}$ ) relative to others that are compatible with an amphibole-rich residue (e.g., Ti, Sm, Yb). Note that the latter feature is common to both the boninites and the Leg 125 peridotites.

In summary, amphibole would fractionate $\mathrm{Sm}$ from $\mathrm{Zr}$ and explain the absence of $\mathrm{Ti}$ and HREE enrichment. Further work is needed to evaluate whether chromatographic fractionation or slab melting is involved. The enrichment in HFSEs indicates that the enrichment is caused by a melt rather than a fluid, although additional enrichment in some elements may take place at lower temperatures.

Table 3. Ion microprobe analysis (ppm) of clinopyroxenes, orthopyroxenes, and olivines from Leg 125 peridotites.

\begin{tabular}{|c|c|c|c|c|c|c|c|c|}
\hline \multirow[b]{3}{*}{ Mineral } & \multicolumn{8}{|c|}{ Conical Seamount } \\
\hline & \multirow[b]{2}{*}{ Clinopyroxene 1} & \multicolumn{2}{|c|}{$779 \mathrm{~A}-14 \mathrm{R}-2,40-48 \mathrm{~cm}$} & \multirow[b]{2}{*}{ Orthopyroxene 1} & \multirow[b]{2}{*}{ Clinopyroxene 1} & \multicolumn{2}{|c|}{$779 \mathrm{~A}-26 \mathrm{R}-2,18-25 \mathrm{~cm}$} & \multirow[b]{2}{*}{ Olivine 1} \\
\hline & & Clinopyroxene 3 & Clinopyroxene 4 & & & Clinopyroxene 3 & Orthopyroxene 1 & \\
\hline $\mathrm{Ti}$ & 133 & 147 & 156 & 59 & 86 & 121 & 43 & 6 \\
\hline V & 148 & 179 & 162 & 111 & 143 & 149 & 109 & 6 \\
\hline $\mathrm{Cr}$ & 3640 & 7408 & 4820 & 4310 & 3296 & 4163 & 3670 & 135 \\
\hline $\mathrm{Sr}$ & 2.52 & 2.71 & 2.45 & 0.29 & 1.00 & 1.38 & 0.63 & 0.41 \\
\hline $\mathrm{Zr}$ & 0.24 & 0.37 & 0.40 & 0.08 & 0.24 & 0.22 & 0.16 & 0.19 \\
\hline $\mathrm{Ce}$ & 0.102 & 0.103 & 0.104 & - & 0.019 & 0.041 & - & - \\
\hline Nd & 0.035 & 0.029 & 0.052 & - & 0.004 & 0.018 & - & - \\
\hline Sm & 0.031 & 0.027 & 0.026 & - & 0.026 & 0.017 & - & $\sim$ \\
\hline $\mathrm{Eu}$ & 0.012 & 0.011 & 0.012 & - & 0.011 & 0.014 & - & - \\
\hline Dy & 0.280 & 0.346 & 0.207 & - & 0.164 & 0.131 & - & - \\
\hline $\mathrm{Yb}$ & 0.369 & 0.336 & 0.331 & - & 0.268 & 0.189 & - & - \\
\hline Hf & 0.097 & 0.097 & 0.117 & - & 0.039 & 0.060 & - & - \\
\hline
\end{tabular}




\section{RELATIONSHIP BETWEEN THE PERIDOTITES AND SPATIALLY-RELATED BONINITES}

The peridotites from Leg 125 are plotted with the boninites from their respective forearcs in Figure 13. Data from the Mariana forearc are plotted in Figure 13A. REE data from three localities were plotted: DSDP Sites 458 and 459 from the outer forearc basin (Hickey and Frey, 1982), dredge site 28 from the inner trench wall (Stern et al., 1991), and the Facpi and Alutom units on Guam (Hickey and Frey, 1982). The boninites from the DSDP sites are LREE depleted and clearly not cogenetic with the harzburgites from Conical Seamount. The boninites from the inner trench wall and the Guam boninites have U-shaped patterns, but distinctly lower $(\mathrm{La} / \mathrm{Sm})_{\mathrm{n}}$ ratios than the harzburgite from Holes 778A and 780C. Data from the Izu-Bonin forearc are plotted in Figure 13B. The REE data are from Chichi-Jima (J. A. Pearce, unpubl. data) and the Leg 125 sites (Murton et al., this volume). As in Figure 13A, the degree of LREE enrichment is much greater in the peridotites from the Torishima Forearc Seamount than in the boninites.

Pearce et al. (chapter 38, this volume) argued that the Leg 125 peridotites are unlikely to be the average residue from the boninites cored at Hole $786 \mathrm{~B}$ as they are too refractory to have been in equilibrium with these boninites. To be cogenetic, the peridotites would have to represent the top of the melting column that produced the boninites and would have undergone the most partial melting. Because $\mathrm{La}$ is more incompatible than $\mathrm{Sm}$ during mantle melting, these most residual peridotites should have much lower $\mathrm{La} / \mathrm{Sm}$ ratios than the extracted melt. As Figure 13 shows, the observed ratios are much higher than those in the melt. Thus, the peridotites cannot be residues from boninite melting unless further trace element enrichment took place after melting.

Despite this evidence that the Leg 125 peridotites were not in equilibrium with the spatially related boninites, the peridotites and boninites from the Izu-Bonin forearc do exhibit similar patterns of trace element enrichment (Pearce et al., chapter 38, this volume), suggesting that any subsolidus enrichment involved fluids similar to those involved in the melting episode.

Because we know the nature and timing of the trace element enrichments and the likely type of melting it is possible to illustrate the relationship between the peridotites and their spatially related boninites using melting and enrichment models. To explain the REE patterns in the peridotites, $(\mathrm{La} / \mathrm{Sm})_{n}$ and $(\mathrm{Sm} / \mathrm{Yb})_{\mathrm{n}}$ ratios were used to emphasize the LREE to MREE enrichment and MREE to HREE depletion, respectively.

As before, an incremental melting model (increments of $0.1 \%$ ) was used to constrain the petrogenesis of the peridotites and the liquids they produce (Fig. 14). An N-MORB source was chosen as a starting composition melt, and the residual compositions were plotted for progressive incremental melting. It is apparent that the resulting compositions have ratios of $\mathrm{La} / \mathrm{Sm}$ and $\mathrm{Sm} / \mathrm{Yb}$ much too low to be suitable boninite sources. To obtain a suitable composition, the residues must be reenriched in the LREEs along a vector similar to that shown in the diagram. The vector was modeled from the enrichment component deduced by Hickey and Frey (1982) and is consistent with the enrichment patterns plotted in this paper. To explain the low $\mathrm{Sm} / \mathrm{Yb}$ ratios in the boninites, it is necessary to invoke $10 \%-15 \%$ melting of the MORB source before enrichment.

Partial fusion of this enriched mantle source to give boninites will again generate residues with much lower ratios of $\mathrm{La} / \mathrm{Sm}$ and $\mathrm{Sm} / \mathrm{Yb}$ than those seen in the Leg 125 boninites. Subsolidus enrichment must again be invoked to give the observed high $\mathrm{La} / \mathrm{Sm}$ ratios. A residue from $10 \%$ to $15 \%$ melting of this boninite source enables modeling of the chemical variations. Note that the spread of $\mathrm{Sm} / \mathrm{Yb}$ ratios in the Leg 125 peridotites is explained by variable degrees of depletion, as indicated by the variable clinopyroxene contents. The resulting model is therefore a multistage one of (1) fusion of MORB mantle to form MORB lithosphere, (2) enrichment of this lithosphere in an LREErich component, (3) fusion of this enriched mantle to generate boninites, and (4) subsolidus enrichment of the most depleted residue from this boninite melting event.

\section{COMPARISON BETWEEN FOREARC PERIDOTITES AND SUPRA-SUBDUCTION ZONE OPHIOLITE MANTLE SEQUENCES}

Compared with peridotite xenoliths and Alpine peridotite massifs, there is a relatively small data base of good trace element analyses for depleted peridotites from ophiolite complexes. Representative REE patterns for harzburgites from supra-subduction zone ophiolites are given in Figure 15. There is a large variation apparent in the REE pattern. HREE values tend to vary by only a factor of 3 , whereas the LREE values vary by up to 2 orders of magnitude, giving a wide range of pattern shapes. Eu anomalies can be positive (e.g., Pindos, Troodos), negative (e.g., New Caledonia), or not detected. The Leg 125 patterns plot within the range of these ophiolitic peridotites, but have steeper LREE profiles (higher $(\mathrm{La} / \mathrm{Sm})_{n}$ ratios) than any of the ophiolite patterns and slightly steeper MREE-HREE profiles $(\mathrm{Sm} / \mathrm{Yb})_{n}$ ratios) than all but the Bay of Islands harzburgites.

Like the Leg 125 peridotites, it is rare for the harzburgites from supra-subduction zone ophiolites to show any obvious relationship to spatially related lavas on the basis of their trace element contents. For example, lavas from Pindos, Troodos, and Semail can have LREEenriched, flat, and LREE-depleted REE patterns, yet the spatially associated harzburgites have flat to LREE-enriched patterns. In the case of the Semail ophiolite, McCulloch et al. (1980) also showed that

Table 3 (continued).

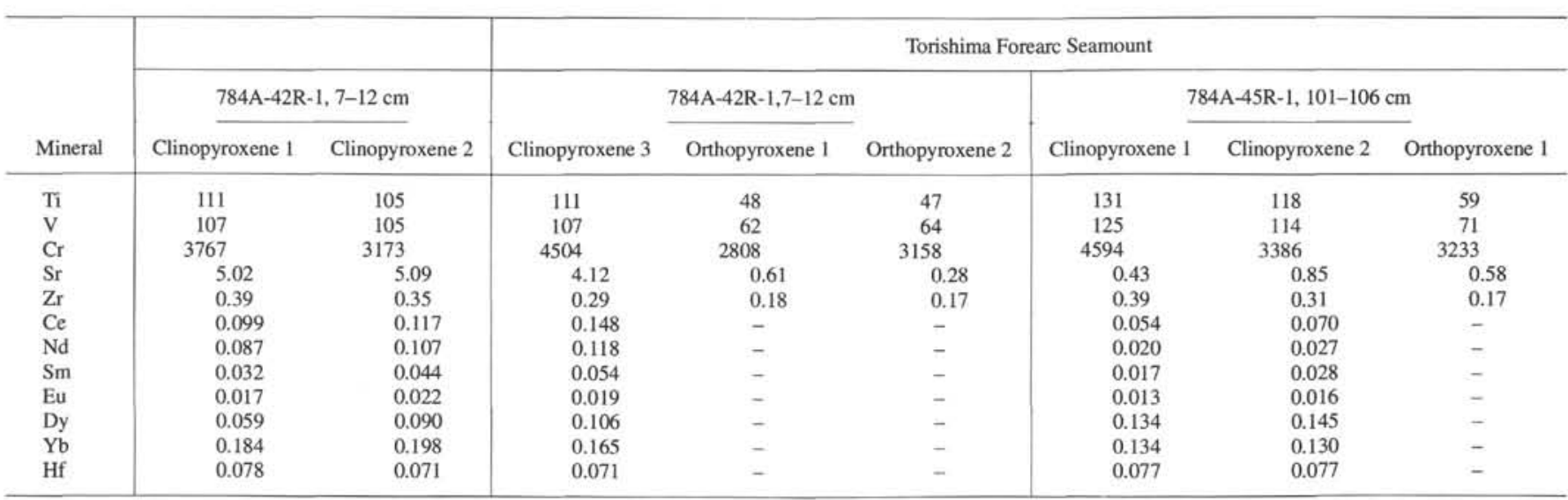


this difference in REE pattern was not matched by a corresponding difference in $\mathrm{eNd}$ values.

\section{SUMMARY}

Our preliminary study of the rare earth and trace element abundances of the Leg 125 peridotites indicates the following.

1. The Leg 125 bulk-rock peridotites have extreme U-shaped chondrite-normalized REE patterns with $(\mathrm{La} / \mathrm{Sm})_{\mathrm{n}}$ ratios in the range of $5.03-250.0$ and $(\mathrm{Sm} / \mathrm{Yb})_{n}$ ratios in the range of $0.05-0.25$, with a possible small positive Eu anomalies in two samples. The peridotites from Conical Seamount have higher La concentrations and lower $\mathrm{Ce}$ and Nd concentrations than the peridotites from Torishima Forearc Seamount. The dunite sample shows similar REE enrichments to the harzburgites.

2. On extended chondrite-normalized patterns, where $\mathrm{Sr}$ is plotted between $\mathrm{La}$ and $\mathrm{Ce}, \mathrm{Zr}$ between $\mathrm{Nd}$ and $\mathrm{Sm}$, and Ti between Gd and Dy, all the peridotites show enrichments (positive anomalies) in $\mathrm{Rb}, \mathrm{Sr}$, and $\mathrm{Zr}$. For feeble peridotites, however, forward modeling shows that at the high degrees of partial melting undergone by the Leg 125 peridotites, positive anomalies of $\mathrm{Sr}, \mathrm{Zr}$, and $\mathrm{Ti}$ are also produced. Thus, to counteract the effect of partial melting the elements need to be plotted in different positions. On the new extended chondrite-normalized patterns, Sr plots between $\mathrm{Nd}$ and $\mathrm{Sm}, \mathrm{Zr}$ between Eu and $\mathrm{Gd}$, and $\mathrm{Ti}$ between $\mathrm{Er}$ and $\mathrm{Yb}$; only $\mathrm{Sr}$ and $\mathrm{Zr}$ show positive anomalies.

3. Ion microprobe analyses show that the diopsides in Leg 125 peridotites have very low trace element concentrations compared with those of abyssal peridotites. However, the Leg 125 diopsides show positive inflections in $\mathrm{Ce}$ and $\mathrm{Nd}$ on a chondrite-normalized REE plot and enrichments in $\mathrm{Zr}$ and $\mathrm{Sr}$ on an extended chondrite-normalized plot. The similarity in trace element patterns between the fresh diopsides and bulk-rock peridotites, coupled with a lack of correlation between trace element enrichment and degree of serpentinization, suggests that low-temperature alteration is unlikely to have affected the trace element concentrations in the peridotites.

4. Forward-melting models show that at least some of the trace element enrichments must have taken place during or after the last melting event. Mass-balance calculations show that the inventory of the highly incompatible trace elements in the peridotite is almost totally from the enriching component and that this component is a melt characterized by high LREEs, $\mathrm{Rb}$, and $\mathrm{Sr}$ contents and high $\mathrm{Zr} / \mathrm{Sm}$ ratios. This type of melt does not resemble an asthenospheric OIB melt unless it is fractionated during its ascent through the mantle wedge, but is more likely derived from the subducted slab.

5 . None of the boninites sampled so far from the Mariana or Izu-Bonin forearcs qualifies as a magma from which the peridotites might be an unmodified residue; none has sufficiently high $(\mathrm{La} / \mathrm{Sm})_{n}$ ratios. It is also unlikely that the peridotites are unmodified sources for any of the Western Pacific boninites.

6 . We developed a multistage melting and enrichment model where the Leg 125 peridotites represent $10 \%-15 \%$ melting of an $\mathrm{N}-\mathrm{MORB}$ source to produce a depleted spinel lherzolite. Enrichment of this lherzolite is followed by a further $10 \%-15 \%$ fusion that produces the spatially related boninites. The peridotites represent the most depleted residues from this melting event. A final enrichment of the peridotites after the second melting event completes the trace element enrichment in the peridotites.

7. The REE patterns of the harzburgite have no obvious equivalents in the harzburgites from supra-subduction zone ophiolites analyzed to date. Although both can have U-shaped patterns and positive Eu anomalies, if supra-subduction zone ophiolites do represent a forearc setting, it is possible that enrichment and depletion events in this setting are highly variable and may reflect the residence time of the mantle in question in the forearc.

\section{ACKNOWLEDGMENTS}

We thank F. A. Frey for his thoughtful comments on the original manuscript. N. K. Lawson and D. K. Kostopoulos are thanked for proofreading several drafts of this manuscript. This research was supported by an NERC (UK) studentship (GT4/89/GS/27) to I.J.P. and an NERC Ocean Drilling Special Topics research grant (GR3/416) to J.A.P.

\section{REFERENCES}

Bloomer, S. H., 1983. Distribution and origin of igneous rocks from the landward slopes of the Mariana Trench: implications for its structure and evolution. J. Geophys. Res., 88:7411-7428.

Bloomer, S. H., and Hawkins, J. W., 1983. Gabbroic and ultramafic rocks from the Mariana Trench: an island arc ophiolite. In Hayes, D. E. (Ed.), The Tectonic and Geologic Evolution of Southeast Asian Seas and Islands (Pt. 2). Am. Geophys. Union, Geophys. Monogr. Ser., 27:294-317.

Boynton, W. V., 1984. Cosmochemistry of the rare earth elements: meteorite studies. In Henderson, P. (Ed.), Rare Earth Element Geochemistry: Amsterdam (Elsevier), 63-114.

Brophy, J. G., and Marsh, B. D., 1986. On the origin of high-alumina arc basalt and the mechanics of melt extraction. J. Petrol., 27:763-789.

Crawford, A. J. (Ed.), 1989. Boninites and Related Rocks: London (Unwin Hyman).

Dobson, P. F., and Tilton, G. R., 1989. Th, U and Pb systematics of boninite series volcanic rocks from Chichi-Jima, Bonin Islands, Japan. In Crawford, A. J. (Ed.), Boninites and Related Rocks: London (Unwin Hyman), 396-415.

Frey, F. A., 1984. Rare earth element abundances in upper mantle rocks. In Henderson, P. (Ed.), Rare Earth Element Geochemistry: Amsterdam (Elsevier), 153-203.

Table 3 (continued).

\begin{tabular}{|c|c|c|c|c|c|}
\hline \multirow[b]{2}{*}{ Mineral } & \multicolumn{3}{|c|}{$784 \mathrm{~A}-45 \mathrm{R}-1,130-137 \mathrm{~cm}$} & \multirow{2}{*}{$\begin{array}{c}\text { Calibration } \\
\text { (working curve) } \\
\text { accuracy }\end{array}$} & \multirow{2}{*}{$\begin{array}{l}\text { Counting } \\
\text { precision } \\
( \pm \%)\end{array}$} \\
\hline & Clinopyroxene 1 & Clinopyroxene 3 & Orthopyroxene 1 & & \\
\hline $\mathrm{T}_{\mathrm{i}}$ & 132 & 127 & 61 & 2 & 3 \\
\hline V & 122 & 131 & 76 & 3 & 2 \\
\hline $\mathrm{Cr}$ & 4214 & 4692 & 3190 & 4 & 3 \\
\hline $\mathrm{Sr}$ & 0.52 & 0.48 & 0.22 & 2 & 14 \\
\hline $\mathrm{Zr}$ & 0.28 & 0.17 & 0.12 & 6 & 33 \\
\hline $\mathrm{Ce}$ & 0.055 & 0.030 & - & 9 & 40 \\
\hline $\mathrm{Nd}$ & 0.013 & 0.011 & - & 15 & 50 \\
\hline Sm & 0.028 & 0.021 & - & 10 & 50 \\
\hline Eu & 0.012 & 0.008 & - & 10 & 50 \\
\hline Dy & 0.142 & 0.121 & - & 20 & 30 \\
\hline $\mathrm{Yb}$ & 0.126 & 0.124 & - & 14 & 25 \\
\hline Hf & 0.082 & 0.043 & - & 35 & 50 \\
\hline
\end{tabular}



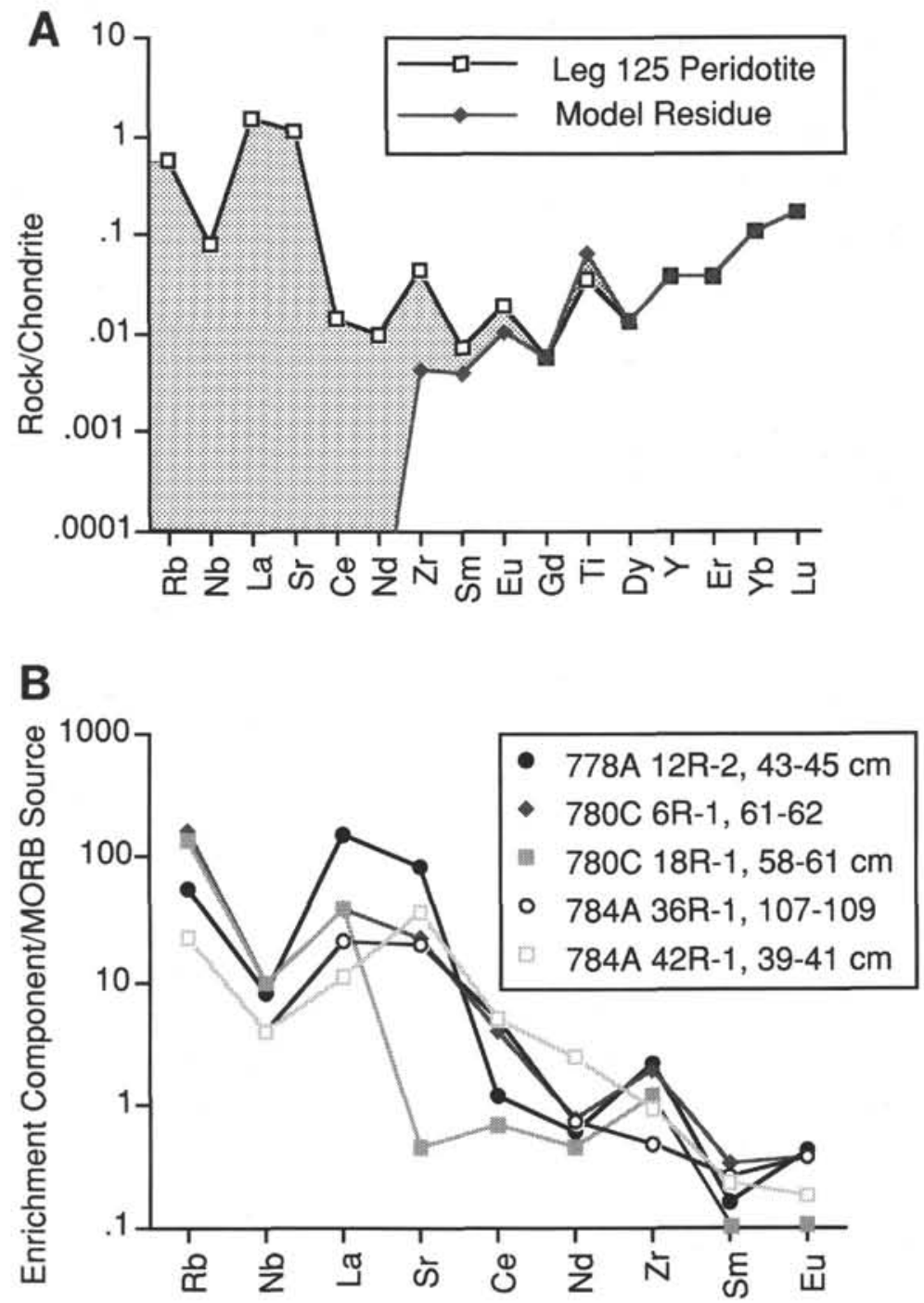

Figure 12. A. Extended chondrite-normalized patterns of a typical Leg 125 peridotite and a forward-modeled (incremental melting) composition of a residual harzburgite for which the HREE values give no enrichment (see text). The shaded area represents the amount of enrichment. The very incompatible elements on the left of the diagram are composed almost totally of the enriched component in the Leg 125 peridotites. B. MORB-source-normalized trace element pattern for the enriching component. The patterns for each peridotite sample are calculated by mass balance assuming that the enriching component makes up $1 \%$ by mass of the peridotite.

Frey, F. A., and Green, D. H., 1974. The mineralogy, geochemistry, and origin of lherzolite inclusions in Victorian basanites. Geochim. Cosmochim. Acta, 38:1023-1059.

Frey, F. A., Suen, C. J., and Stockman, H. W., 1985. The Ronda high temperature peridotite: geochemistry and petrogenesis. Geochim. Cosmochim. Acta, 49:2469-2491.

Fryer, P., and Fryer, G. J., 1987. Origins of non-volcanic seamounts in a forearc environment. In Keating, B. H., Fryer, P., Batiza, R., and Boehlert, G. W. (Eds.), Seamounts, Islands and Atolls. Am. Geophys. Union, Geophys. Monogr. Ser., 43:61-69.

Fryer, P., Pearce, J. A., Stokking, L. B., et al., 1990. Proc. ODP, Init. Repts., 125: College Station, TX (Ocean Drilling Program).

Gast, P. W., 1968. Trace element fractionation and the origin of tholeiitic and alkaline magmas types. Geochim. Cosmochim. Acta, 32:1057-1086.
Govindaruju, K., 1989. Compilation of working values and sample descriptions for 272 geostandards. Geostand. Newsl., 13:1-113.

Green, T. H., Sie, S. H., Ryan, C. G., and Cousens, D. R., 1989. Proton microprobe determined partitioning of $\mathrm{Nb}, \mathrm{Ta}, \mathrm{Zr}$, Sr and $\mathrm{Y}$ between garnet, clinopyroxene and basaltic magmas at high pressure and temperature. Chem. Geol., 74:201-216.

Hickey, R. L., and Frey, F. A., 1982. Geochemical characteristics of boninite series volcanics: implications for their sources. Geochim. Cosmochim. Acta, 46:2009-2115.

Hickey-Vargas, R., 1989. Boninites and tholeiites from DSDP Site 458, Mariana forearc. In Crawford, A. J. (Ed.), Boninites and Related Rocks: London (Unwin Hyman), 339-356.

Ishii, T., 1985. Dredged samples from the Ogasawara forearc seamount or "Ogasawara Paleoland"- "forearc ophiolite." In Nasu, N., Kobayashi, K., 


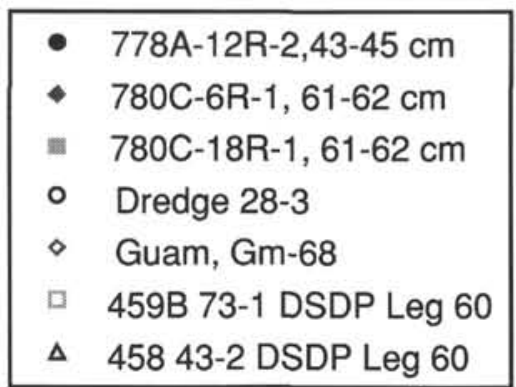

A
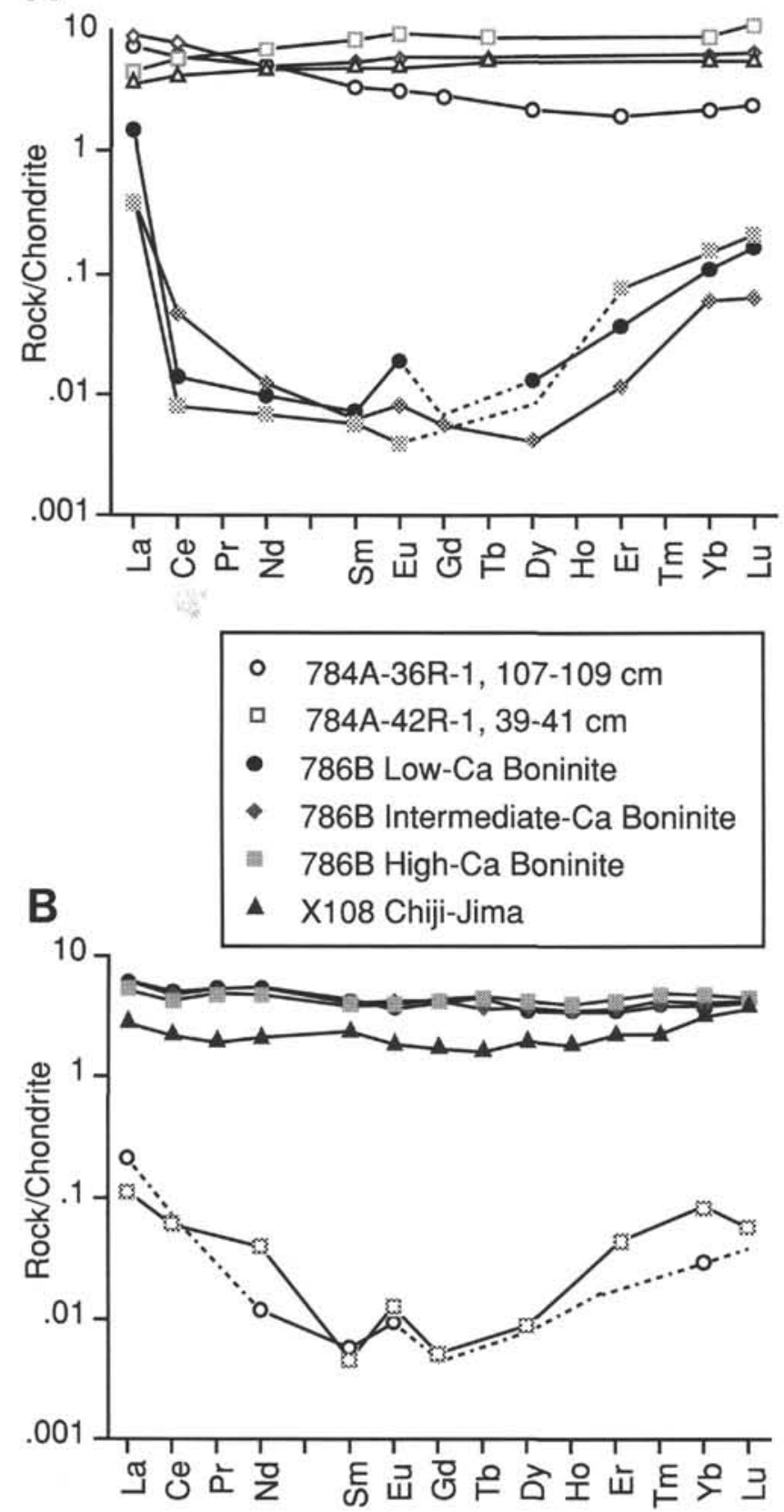

Figure 13. Chondrite-normalized REE patterns of Leg 125 peridotites with spatially related boninites from (A) the Mariana forearc and Guam and (B) the Izu-Bonin forearc. Data for the Mariana boninites are from Hickey and Frey (1982), Hickey-Vargas (1989), Stern et al. (1991); for Izu-Bonin from Murton et al. (this volume) and J. A. Pearce (unpubl. data).

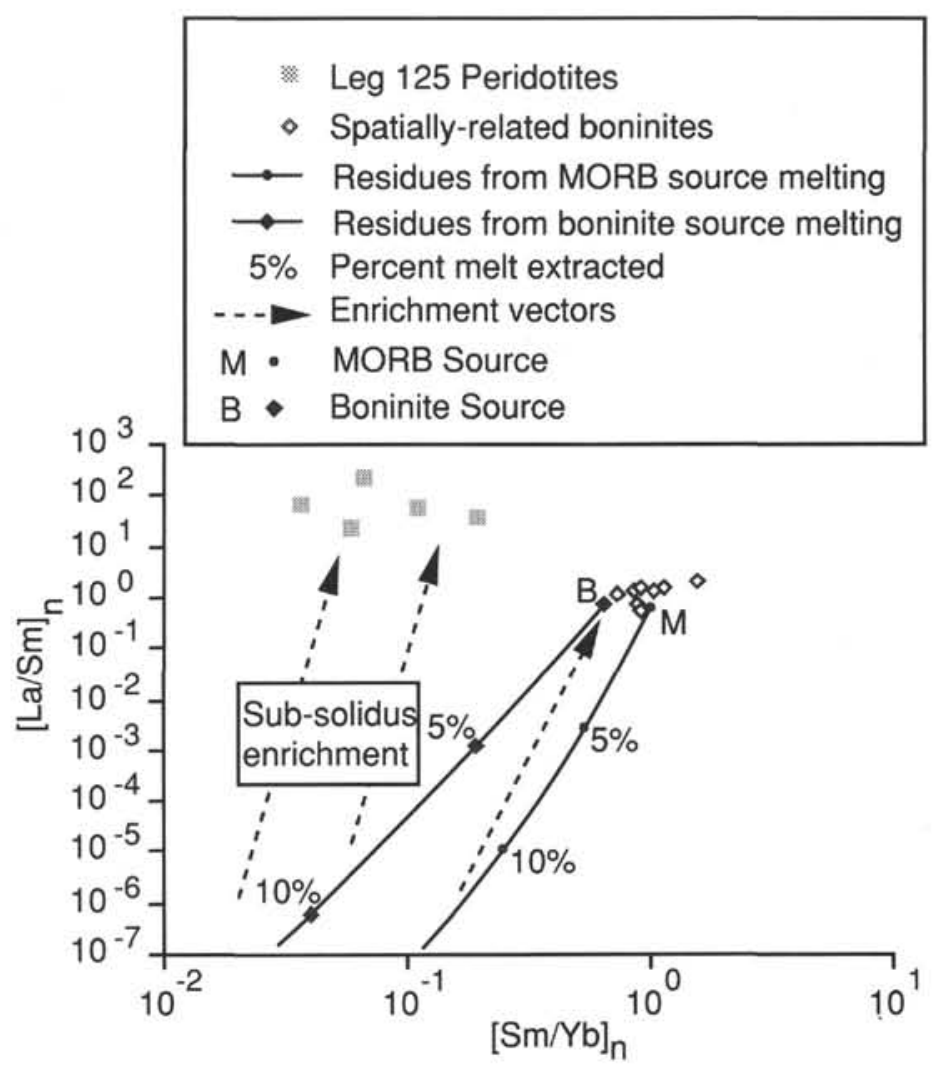

Figure 14. Plot of $(\mathrm{La} / \mathrm{Sm})_{n}$ vs. $(\mathrm{Sm} / \mathrm{Yb})_{n}$ showing a possible relationship between the Leg 125 peridotites and spatially related boninites. Solid lines represent depletion trends and the dotted lines the enrichment trends. The boninite source represents the residue from $10 \%-1 \%$ partial melting of an $\mathrm{N}-\mathrm{MORB}$ source enriched by the enriching components calculated in Hickey and Frey (1982). Residues from remelting of this source are reenriched (see Figure 12B and the text) under subsolidus conditions to produce the Leg 125 peridotites.

Uyeda, S., Kushiro, I., and Kagami, H., (Eds.), Formation of Active Ocean Margins: Tokyo (Terra Sci. Publ.), 307-342.

Ishiwatari, A., 1985. Igneous petrogenesis of the Yakuma ophiolite (Japan) in the contest of the diversity of ophiolites. Contrib. Mineral. Petrol., 89:155-167.

Jaques, A. L., and Green, D. H., 1980. Anhydrous melting of peridotite, $0-15 \mathrm{~kb}$ pressure and the genesis of tholeite basalts. Contrib. Mineral. Petrol., 73:287-310.

Jochum, K. P., Seifert, H. M., and Thirlwall, M. F., 1990. High-sensitivity Nb analysis by spark-source mass spectrometry (SSMS) and calibration of XRF Nb and Zr. Chem. Geol., 81:1-16.

Johnson, K.T.M., Dick, H.J.B., and Shimizu, H., 1990. Melting in the oceanic upper mantle: an ion microprobe study of diopside in abyssal peridotites. J. Geophys. Res., 95:2661-2678.

Kay, R. W., and Senechal, R. G., 1976. The rare earth geochemistry of the Troodos ophiolite complex. J. Geophys. Res., 81:964-970.

Kelemen, P. B., Johnson, K.J.M., Kinzler, R. J., and Irving, A. J., 1990. High-field-strength element depletions in arc basalts due to mantle-magma interaction. Nature, 345:521-524.

Kostopoulos, D. K., 1991. Melting of the shallow upper mantle: a new perspective. J. Petrol., 32:671-699.

Leg 125 Shipboard Scientific Party, 1989. Plumbing the Pacific sinks. Nature, 339:427-428.

Lippard, S. J., Shelton, A. W., and Gass, I. G., 1986. The Ophiolite of Northern Oman. Geol. Soc. London Mem., 11.

Masutami, Y., Yamamoto, K., Nakamura, N., and Ishii, T., 1988. Geochemical study of the origin of forearc ophiolite in the Ogasawara region (in Japanese). Annu. Meet. Geochem. Soc. Jpn. Abstr., 180.

McCulloch, M. T., Gregory, R. T., Wasserburg, G. J., and Taylor, H. P., Jr., 1980. A neodymium, strontium, and oxygen isotopic study of the 


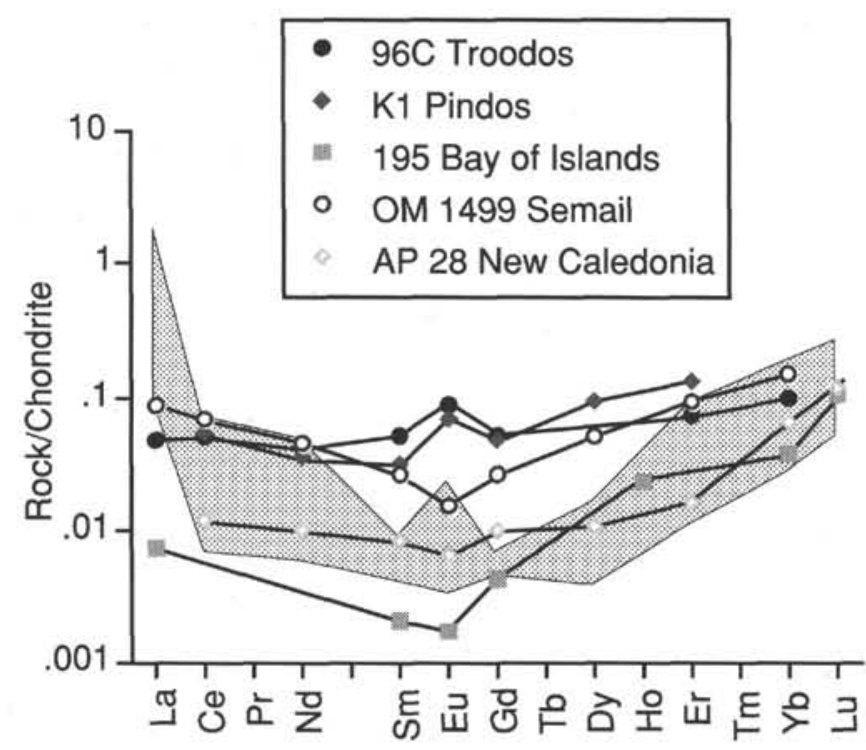

Figure 15. Chondrite-normalized REE patterns of harzburgites from selected supra-subduction zone ophiolites. The shaded field represents the Leg 125 peridotites. Data from the Bay of Islands (Suen et al., 1979), Semail (Lippard et al., 1986), Troodos (Kay and Senechal, 1976), Pindos (Montigny et al., 1973), and New Caledonia (Prinzhofer and Allègre, 1985).

Cretaceous Semail ophiolite and implications for the petrogenesis and seawater-hydrothermal alteration of oceanic crust. Earth Planet. Sci. Lett., 23:8-14.

McDonough, W. F., 1991. Partial melting of subducted oceanic crust and isolation of its residual eclogitic lithology. Philos. Trans. R. Soc. LondonA, 335:407-418.

McDonough, W. F., and Frey, F. A., 1989. Rare earth elements in upper mantle rocks. In Lipin, B. R., and McKay, G. A. (Eds.), Geochemistry and Mineralogy of Rare Earth Elements. Rev. Mineral., 21:99-145.

McKenzie, D. P., 1989. Some remarks on the movement of small melt fractions in the mantle. Earth Planet. Sci. Lett., 95:53-72.

Montigny, R., Bougault, H., Bottinga, Y., and Allègre, C. J., 1973. Trace element geochemistry and the genesis of the Pindus ophiolite suite. Geochim. Cosmochim. Acta, 37:2135-2147.

Navon, O., and Stolper, E., 1987. Geochemical consequences of melt percolation: the upper mantle as a chromatographic column. J. Geol., 95:285-307.

Ottonello, G., Piccardo, G. B., and Ernst, W. G., 1979. Petrogenesis of some Lingurian peridotites-II. Rare earth element chemistry. Geochem. Cosmochim. Acta, 43:1273-1284.

Pallister, J. A., and Knight, R. J., 1981. Rare earth element geochemistry of the Semail ophiolite near Ibra, Oman, J. Geophys. Res., 86:2673-2697.

Pearce, J. A., Lippard, S. J., and Roberts, S., 1984. Characteristics and tectonic significance of supra-subduction zone ophiolites. In Kokelaar, B. P., and Howells, M. F. (Eds.), Marginal Basin Geology. Geol. Soc. Spec. Publ. London, 16:77-94.

Prinzhofer, A., and Allègre, C. J., 1985. Residual peridotites and the mechanisms of partial melting. Earth Planet. Sci. Lett., 74:251-265.

Sakai, R., Kusuakabe, M., Noto, M., and Ishii, T., 1990. Origin of water responsible for serpentinization of the Izu-Ogasawara-Mariana forearc seamounts in view of hydrogen and oxygen isotope ratios. Earth Planet. Sci. Lett., 100:291-303.

Salters, V.J.M., 1989. Anhydrous HFSE depleted peridotites as a ubiquitous mantle component. In Hart, S. R., and Gulen, L. (Eds.), Crust/Mantle Recycling at Convergent Zones: Dordrecht (Kluwer Academic Press), $105-119$.

Salters, V.J.M., and Shimizu, N., 1988. World-wide occurrence of HSFEdepleted mantle. Geochim. Cosmochim. Acta, 52:2177-2182.

Shaw, D. M., 1970. Trace element fractionation during anatexis. Geochim. Cosmochim. Acta, 34:237-243.

Stern, R. J., Morris, J., Bloomer, S. H., and Hawkins, J. W., Jr., 1991. The source of the subduction component in convergent margins: trace element and radiogenic isotope evidence from Eocene boninites, Mariana forearc. Geochim. Cosmochim. Acta, 55:1467-1481.
Stosch, H.-G., 1982. Rare earth element partitioning between minerals from anhydrous spinel peridotite xenoliths. Geochim. Cosmochim. Acta, 46:793-811.

Stosch, H.-G., and Seck, H. A., 1980. Geochemistry and mineralogy of two spinel peridotite suites from Dreiser Weiher, West Germany. Geochim. Cosmochim. Acta, 44:457-470.

Suen, C. J., Frey, F. A., and Malpas, J., 1979. Bay of Islands ophiolite suite, Newfoundland: petrologic and geochemical characteristics with emphasis on the rare earth element geochemistry. Earth Planet. Sci. Lett., 45:337-348.

Sun, S. S., and McDonough, W. F., 1989. Chemical and isotopic systematics of oceanic basalts: implications for mantle composition and processes. In Saunders, A. D., and Norry, M. J. (Eds.), Magmatism in the Ocean Basins. Spec. Pap.-Geol. Soc. London, 42:313-345.

Tatsumi, Y., Hamilton, D. L., and Nesbitt, R. W., 1986. Chemical characteristics of fluid phase released from a subducted lithosphere and the origin of arc magmas: evidence from high-pressure experiments and natural rocks. J. Volcanol. Geotherm. Res., 29:293-309.

Taylor, B., and Smoot, N. C., 1984. Morphology of Bonin forearc submarine canyons. Geology, 12:724-727.

Thirlwall, M. F., 1982. A triple-filament method for the rapid and precise analysis of rare-earth elements by isotope dilution. Chem. Geol., 35:155-166.

Woodhead, J. D., 1989. Geochemistry of the Mariana arc (Western Pacific): source composition and processes. Chem. Geol., 76:1-24.

\section{Date of initial receipt: 27 September 1990}

Date of acceptance: 22 October 1991

Ms 125B-183

\section{APPENDIX}

\section{Melting Equations}

Melting equations from Gast (1968) and Shaw (1970) were used to model the trace element concentration of melts, whole-rock residues, and residual clinopyroxenes during partial melting of a fertile lherzolite source. The starting mode is a fertile spinel lherzolite $\left(\mathrm{Ol}_{58} \mathrm{Opx}_{25} \mathrm{Cpx}_{15} \mathrm{Sp}_{2}\right)$ similar to that suggested by Kostopoulos (1991), with a starting composition that is LREE depleted ( 1 to 2 times chondrite). The melting modes used in the modeling are shown in Appendix Table 1. Mineral/liquid distribution coefficients for the REEs, $\mathrm{Zr}$, and $\mathrm{Ti}$ shown in Appendix Table 2 are taken from the compiled values of Kelemen et al. (1990), except Rb, which are taken from Brophy and Marsh (1986), and $\mathrm{Sr}$ and $\mathrm{Nb}$ from Green et al. (1989). $\mathrm{Y}$ is estimated from $\mathrm{Er}$ and $\mathrm{Dy}$ and $\mathrm{Lu}$ is estimated from $\mathrm{Yb}$ so that these measurements are consistent with the other REE elements. Three types of melting were used in the modeling.

\section{Equilibrium Batch Melting}

Equilibrium batch melting is given by the expression

$$
C_{i} l / C_{i} o=\left[D_{i} o+F(1-P)\right],
$$

where $C_{i} l$ is the concentration of element $i$ in the liquid, $C_{i} o$ is the concentration of $i$ in the original bulk solid, $F$ is the weight proportion of melt formed, and $D_{i} O$ is the initial bulk distribution coefficient of element $i . C_{i} s$, the concentration of $i$ in the residue, is given by

$$
C_{i} s / C_{i} o=\left[D_{i} o-P F\right) /(1-\mathrm{F}]\left[1 /\left(D_{i} o+F(1-P)\right)\right] .
$$

The trace element concentration of clinopyroxene was calculated using equation A6 derived in Johnson et al. (1990):

$$
C_{i} c p x / / C_{i} o=\left[D^{c p x l} /\left(D_{i} o+F(1-P)\right)\right],
$$

where $D^{c p x l}$ is the clinopyroxene/liquid distribution coefficient and $C_{i} c p x$ is the concentration of $i$ in the clinopyroxene. 


\section{Incremental Batch Melting}

Similar equations were used as previously except the melting was incremented in $0.1 \%$ steps and a new initial composition used after each increment. Both instantaneous and average pooled melt compositions are calculated assuming perfect mixing.

\section{Fractional Melting}

The concentration of element $i$ in the liquid is calculated from the expression

$$
C_{i} l / C_{i} o=\left[1 / D_{i} o\right]\left[1-\left(P F / D_{i} o\right)\right]^{(1 / P-1)} .
$$

The concentration of element $i$ in the residue is

$$
\mathrm{C}_{i} s / C_{i} o=\left[\left(D_{i} o-P F\right) /(1-F)\right]\left[1 /\left(D_{i} o+F(1-P)\right)\right] .
$$

The concentration of element $i$ in the clinopyroxene was calculated using equation A4 from Johnson et al. (1990) is

$$
C_{i} c p x / C_{i} o=\left[1-(P F) / D_{i} o\right]^{1 / P} \cdot\left[D_{i} c p x / 1 / D_{i} o-P F\right] .
$$

Appendix Table 1. Phase proportions used in forward modeling.

\begin{tabular}{lllll}
\hline Element & Olivine & Orthopyroxene & Clinopyroxene & Spinel \\
\hline $\mathrm{Rb}$ & 0.0001 & 0.02 & 0.01 & 0.0006 \\
$\mathrm{Nb}$ & 0.0001 & 0.001 & 0.01 & 0.1 \\
$\mathrm{Sr}$ & 0.01 & 0.04 & 0.06 & 0.0006 \\
$\mathrm{La}$ & 0.000007 & 0.0025 & 0.04 & 0.0006 \\
$\mathrm{Ce}$ & 0.00001 & 0.005 & 0.13 & 0.0006 \\
$\mathrm{Nd}$ & 0.00007 & 0.01 & 0.25 & 0.0006 \\
$\mathrm{Sm}$ & 0.0007 & 0.02 & 0.45 & 0.0006 \\
$\mathrm{Eu}$ & 0.00095 & 0.03 & 0.5 & 0.0006 \\
$\mathrm{Gd}$ & 0.0012 & 0.04 & 0.5 & 0.0006 \\
$\mathrm{Dy}$ & 0.004 & 0.05 & 0.51 & 0.0015 \\
$\mathrm{Er}$ & 0.009 & 0.07 & 0.52 & 0.003 \\
$\mathrm{Yb}$ & 0.023 & 0.11 & 0.52 & 0.0045 \\
$\mathrm{Lu}$ & 0.04 & 0.15 & 0.55 & 0.006 \\
$\mathrm{Zr}$ & 0.007 & 0.07 & 0.2 & 0.15 \\
$\mathrm{Ti}$ & 0.015 & 0.15 & 0.3 & 0.07 \\
$\mathrm{Y}$ & 0.006 & 0.06 & 0.51 & 0.002 \\
\hline
\end{tabular}

Appendix Table 2. Mineral/liquid distribution coefficients used in forward modeling.

\begin{tabular}{lcc}
\hline Mineral & $\begin{array}{c}\text { Starting mode } \\
\text { (wt\%) }\end{array}$ & $\begin{array}{c}\text { Melting mode } \\
\text { (wt\%) }\end{array}$ \\
\hline Olivine & 58 & 0.10 \\
Orthopyroxene & 25 & 0.28 \\
Clinopyroxene & 15 & 0.60 \\
Spinel & 2 & 0.02 \\
\hline
\end{tabular}

